\title{
THE CONSTITUTIONAL STATUS OF THE LAWFULLY ADMITTED PERMANENT RESIDENT ALIEN: THE PRE-1917 CASES*
}

\author{
SIEGFRIED HESSE $\dagger$
}

Theory is the most important part of the dogma of the law, as the architect is the most important man who takes part in the building of a house .... It is not to be feared as unpractical for, to the competent, it simply means going to the bottom of the subject.

Mr. Justice Holmes ${ }^{1}$

AfTER the decision of the Supreme Court in Harisiades v. Shanghnessy ${ }^{2}$ in 1952, the power of Congress to expel long-term resident aliens seemed a firmly settled constitutional concept. ${ }^{3}$ Harisiades involved three aliens, all of whom had entered the United States, as minors, prior to 1921. During their residence in this country, each had joined the Communist Party. One resigned in 1929 and another in 1938, while the third was expelled in 1939, although he still believed in party principles. Not having acted against them earlier, the Government moved in 1946 to expel them ${ }^{4}$ under the Alien Registration Act of $1940,{ }^{5}$ which made former membership in an organization advocating overthrow of the government by force or violence grounds for an alien's expulsion. ${ }^{6}$ The act, as applied, was upheld by the Harisiades majority, which determined that congressional power in this area was "largely immune from judicial inquiry or interference." Deportation of a long-term resident alien was variously viewed as a matter of the war and foreign relations powers, "inherent sovereignty," and "the maintenance of a.republican form of government." But only two years later the question was reconsidered in Galvan $v$.

*The first of two Articles by the author. The second will appear in an early issue of volume 69.

† Managing Legal Editor, California Continuing Education of the Bar. The views expressed here are those of the author, and do not necessarily represent those of either the State Bar of California or the University of California Extension, which administers the program.

1. Holmes, The Path of the Lazw, 10 HARv. L. REv. 457, 477 (1897).

2. 342 U.S. 580 (1952).

3. See Mulcahey v. Catalanotte, 353 U.S. 692 (1957) ; Lehmann v. United States ex rel. Carson, 353 U.S. 685 (1957) ; Rabang v. Boyd, 353 U.S. 427 (1957); Marcello v. Bonds, 349 U.S. 302 (1.955).

4. 342 U.S. at $581-83$.

5. Ch. 439,54 Stat. 670 . Portions of this act are still in force, but the deportation provisions are now found, with some changes, in the Immigration and Nationality Act of 1952, § 241, 66 Stat. 204-08, 8 U.S.C. § 1251 (1952).

6. Ch. 439,54 Stat. 670,673 (1940); see 342 U.S. at 588 n.15.

7. 342 U.S. at $587-89$. 
Press, ${ }^{8}$ with the same result. In 1956 , Rowoldt $v$. Perfetto ${ }^{9}$ reopened it again, but questionable statutory construction avoided both banishment and the constitutional issue. ${ }^{10}$ Thus, the peacetime status of the long-term resident alien remains subject to examination.

It is appropriate, therefore, both to determine what has caused the Court's dilemma between its own recent precedents and the extremity of banishment, and, more important, to suggest a more fitting constitutional view of congressional power in the conflict between the legitimate need for regulation of immigration and the rights of resident aliens. ${ }^{11}$

Strangely enough, not until Harisiades did the Court sanction banishment in the face of substantive due process objections. ${ }^{12}$ The inquiry undertaken, however, is not to establish that the early judicial statements there relied upon were dicta, but rather that the actual theory of the prior cases rested upon a rationale which does not support the result there reached.

8. 347 U.S. 522 (1954).

9. 355 U.S. 115 (1957).

10. The questions presented were the sufficiency of the evidence, and whether Galvan should be overruled. The majority opinion only considered the first question. Id. at 1.16, 120. The dissenting opinion noted and rejected the latter question although reserving decision on the scope of substantive due process limitations for future cases. Id. at 126 .

11. Since the inquiry involves constitutional questions, stare decisis raises no insurmountable barrier. Smith v. Allwright, $321 \mathrm{U}_{\alpha} \mathrm{S}$. 649, 665 (1944); Burnet v. Coronado Oil \& Gas Co., 285 U.S. 393, 405-11 (1932) (dissenting opinion of Brandeis, J.). This is particularly true in this area, since the recent opinions purport to be based on precedents developed under significantly different legislation. While the basic view espoused here is different, the debt owed to the late Louis B. Boudin for his germinal study, The Settler IVithin Our Gates (pts. 1-3), 26 N.Y.U.L. Rev. 266, 451, 634 (1951.), is as extensive as it is obvious. His position was rejected in Harisiades, although, in view of Rowoldt, the substantive due process argument remains vital. For a post-Harisiades statement of this argument, see Bullitt, Deportation as a Denial of Substantive Due Process, 28 WASH. L. REv. 205 (1953).

Valuable sociological material is available in Lowenstern, The Alten AND the IMMigration Law 164-284 (1957); Committee on Immigration and Naturalization, Political Deportations in the United States, 14 LAw. GuInD REv. 93 (1954), supplemented (with some overlap in cases covered) by Appendix to Brief for Petitioner, Rowoldt v. Perfetto, 355 U.S. 115 (1957).

There has been surprisingly little academic interest in immigration law generally. See Oppenheimer, Book Review, 65 Y ALE L.J. 115 (1955). The recent decisions have been criticized, but primarily on the basis of policy, rather than power. See, e.g., Comment, 20 U. Chr. L. Rev. 547 (1953); Note, 37 Mrnn. L. Rev. 440 (1953). The President's Commission likewise did not question congressional power. See U.S. PRESIDENT'S CoMn'N on Imamigration and Naturalization, Report-Whom We Shall Welcome 175 (1953) [hereinafter cited as President's Comm'N Rep.]. See generally Alexander, Rights of Aitens under the Federal Constitution (1931); Konvitz, Crvil Rights in Immigration (1953), and The Alien and the Asiatic in American Law (1946). See Sarith, Freedoar's Fetters (1956); Miller, Crisis In Freedom (1951), concerning the Alicn and Sedition Acts of 1798 .

12. But see S. REp. No. 1515, 81st Cong., 2d Sess. 45 (1950) (The expulsion "power is not dependent upon the existence of statutory conditions as to his [the alien's] right to remain at the time he became a resident," citing United States v. Sui Joy, 240 Fed. 
Two cases, Fong Yue Ting v. United States ${ }^{13}$ and Bugajerritz v. Adams, ${ }^{14}$ are the twin foundations upon which the current constitutional theory of unlimited congressional power over all aliens is erected. ${ }^{15}$ A third, Keller $v$. United States, ${ }^{16}$ held an attempted exercise of the power to regulate immigration unconstitutional on substantive grounds. Perhaps because the legislation voided in Keller involved criminal penalties for both citizens and aliens, rather than expulsion of aliens, ${ }^{17}$ its potentially far-reaching significance has been totally ignored since shortly after its pronouncement. This study will undertake to show that neither Fong Yue Ting nor Bugajezitz unquestionably supports Harisiades, but that both can be harmonized with the Keller rationale, which is totally inconsistent with (and not mentioned in) Harisiades.

\section{The Problem of Definition}

There is nothing startling about returning a person to his native country shortly, or a few years, after arrival when he was erroneously allowed to enter, or achieved his residence fraudulently or by other illegal means. On the other hand, when admittance is attained lawfully and properly, and the entire life of a human being, or several human beings, is changed as a consequence, the retraction of the right to permanent residence suggests a different constitutional picture.

Failure to appreciate the distinction between these qualitatively different situations has been, at least in part, the by-product of the failure to distinguish between different types of expulsion. Drawing a distinction only between exclusion and expulsion, the Court has accepted as useful in immigration cases the term "exclusion," meaning "preventing someone from entering the United States who is actually outside of the United States or is treated as being so"; the term "expulsion," meaning "forcing someone out of the United States who is actually within the United States or is treated as being so"; and the term "deportation," signifying "the moving of someone away from the United States, after exclusion or expulsion."18

This usage of "expulsion," however, lumps the illegally and erroneously admitted resident together with the long-term, lawful resident. It blurs, and impliedly negatives, any difference in constitutional status. In this Article, for purposes of clarity, the expulsion of one who either entered illegally, or who, within a reasonable time after entry, committed acts justifying the conclusion

392 (9th Cir. 1917). The case involved the power to expel from Hawaii persons who had established residence there prior to its annexation. It is distinguishable from the views presented hereafter, since there had never been an opportunity for an initial screening).

13. 149 U.S. 698 (1893).

14. 228 U.S. 585 (1913).

15. See Dezelopments in the Laze-Immigration and Nationality, 66 HARv. L. Rev. 643, 681 (1953).

16. 213 U.S. 138 (1909).

17. Id. at 139 .

18. See Kwong Hai Chew v. Colding, 344 U.S. 590, 596 n.4 (1953). 
that entry was erroneously allowed, will be termed "ejection." The expulsion of one who committed an act which either by its nature, or by its temporal remoteness to entry, affords no basis for a presumption of initial excludability will be termed "banishment." 19 When "expulsion" is used hereafter, it is meant to include both ejection and banishment.

\section{Banishment and Statutory Construction}

Strict construction of expulsion statutes is an accepted principle. ${ }^{20}$ Often used to prevent harsh results, strict construction appears to be an implicit, if unarticulated, recognition of the distinction between ejection and banishment. ${ }^{21}$ It also seems to explain why few expulsion cases seriously broach the question of substantive limits to congressional power. The interests of the alien involved are far better served by counsel's urging a statutory loophole than by an attack on broad doctrinal grounds. As a consequence, the constitutional issues presented by expulsion have been considered only in cases involving extremely unpopular groups of aliens, whose very unpopularity has led to their explicit inclusion within the orbit of congressional intent. It is not surprising, therefore, that the leading immigration cases seriously considering constitutional issues have, in historical order, involved Chinese laborers, ${ }^{22}$

19. That expulsion may constitute banishment has been repeatedly recognized, although no legal distinction has yet followed. See, e.g., Barber v. Gonzales, 347 U.S. 637, 642 (1954) ; Galvan v. Press, 347 U.S. 522, 530 (1954); Fong Haw Tan v. Phelan, 333 U.S. 6, 10 (1948); Ng Fung Ho v. White, 259 U.S. 276, 281 (1922) ; Madison, Report on the Virginia Resolutions, 4 Elliot, Debates on the Federal Constitution 555 (1\$66) [hereinafter cited as Ellior's Debates].

20. "Although not penal in character, deportation statutes as a practical matter may inflict "the equivalent of banishment or exile' . . . and should be strictly construed." Barber v. Gonzales, 347 U.S. 637, 642-43 (1954); see Jordan v. DeGeorge, 341 U.S. 223, 231 (1951) ; Fong Haw Tan v. Phelan, 333 U.S. 6, 10 (1948) ; Delgadillo v. Carmichael, 332 U.S. 3SS, 391. (1947). This type of reasoning is fully displayed in the opinion of Judge L. Hand in Di Pasquale v. Karnuth, 158 F.2d 878, 879 (2d Cir. 1947).

21. The opinion in Rowoldt v. Perfetto, 355 U.S. 115 (1957), is a recent example of the method by which the courts seek to avoid the banishment of long-term residents. Mr. Justice Frankfurter, holding that Congress had not intended to authorize deportation of the petitioner, stated that "the differences on the facts between Galvan v. Press ... and this case are too obvious to be detailed." Id. at 121. In fact, the evidence in support of the contention that an expellable act was committed seems stronger in Rowoldt. Compare id. at 127-30 with the facts in Galvan v. Press, 347 U.S. 522, 524 (1954). Rowoldt was "an old man who has lived in this country for forty years." 355 U.S. at 120. This fact would be irrelevant under the current view of the extent of Congress' constitutional powers over aliens, and only by strained construction could it be at all relevant to congressional intent in the statute involved, Internal Security Act of 1950, ch. 1024, $\$ 22,64$ Stat. 1006. The substance of the relevant provisions was incorporated into Immigration and Nationality Act of 1952, $\S$ 212(a) (28)-(29) (exclusion), 241 (a) (6)-(7) (deportation), 66 Stat. 184, 205, \& U.S.C. \$\$ 1182(a) (28)-(29), 1251:(a) (6)-(7) (1952).

22. Fong Yue Ting v. United States, 149 U.S. 698 (1893); Chae Chan Ping v. United States, 130 U.S. 581 (1889). 
anarchists, ${ }^{23}$ prostitutes, ${ }^{24}$ convicted wartime saboteurs, ${ }^{25}$ and, in the present decade, ex-communists. ${ }^{26}$

Thus, congressional power to eject and banish has been contested only under the most unfavorable circumstances. The fact that principles of law arise out of hard or sordid cases does not mean that they are wrong, ${ }^{27}$ but it does justify a careful scrutiny of the cases. ${ }^{28}$

\section{Sources of Federal Power Over Aliens}

There are some phenomena to which it is not enough to assign one canse: we must enumerate several, though in fact there is only one.

Lucretius $^{20}$

It is striking that no power to regulate immigration is specifically mentioned in the Constitution. ${ }^{30}$ This, however, does not automatically establish congressional omnipotence over aliens. It might equally suggest an absence of power to expel except in time of war. This view, in fact, enjoyed the support of both Madison ${ }^{31}$ and Jefferson. ${ }^{32}$

Aside from the naturalization power, four sources of an implied power to expel have been suggested: the war power, the foreign commerce power, the treaty power, and sovereignty itself. Absent a governing treaty or war, however, the foreign commerce power seems the only proper basis for expulsion.

23. United States ex rel. Turner v. Williams, 194 U.S. 279 (1904).

24. Lapina v. Williams, 232 U.S. 78 (1914); Bugajewitz v. Adams, 228 U.S. 585 (1913) ; Zakonaite v. Wolf, 226 U.S. 272 (1912); Low Wah Suey v. Backus, 225 U.S. 460 (1912).

25. Mahler v. Eby, 264 U.S. 32 (1924).

26. Galvan v. Press, 347 U.S. 522 (1954); Harisiades v. Shaughnessy, 342 U.S. 580 (1952).

27. But see Boudin, supra note 11 , at $651-52$, quoting from Mr. Justice Frankfurter's opinion in United States v. Rabinowitz, 339 U.S. 56, 68 (1940) (sordid cases make bad law).

28. To root up all those associations which we call home, to banish him [the alien] to be an outcast in a country of whose traditions and habits he knows nothing, and where his alienage is a daily, living fact, not a legal imputation-these are consequences whose warrant we may properly scrutinize with some jealousy, and insist that logic shall not take the place of understanding.

United States ex rel. Mignozzi v. Day, 51 F.2d 1019, 1021 (2d Cir. 1931) (L. Hand, J.).

29. Lucretius, The Nature of tee Universe 238 (Latham trans1. 1951). (Italics deleted.)

30. See Harisiades v. Shaughnessy, 342 U.S. 580, 599 (1952) (dissenting opinion of Douglas, J.).

31. "With respect to aliens who are not enemies, but members of nations in peace and amity with the United States, the power assumed by the [Alien] act [of 1798] of Congress is denied to be constitutional, ..." Madison, Report on the Virginia Resolutions, 4 Elizor's Debates 546, 554.

32. "[A]lien friends are under the jurisdiction and protection of the laws of the state wherein they are $;. .$. no power over them has been delegated to the United States ... [accordingly] the [Alien] act [of 1798] ... is not law, but is altogether void and of no force." Jefferson, Kentucky Resolutions of 1798 and 1799, 4 id. at 540-41. See also Johnson v. Eisentrager, 339 U.S. 763, 774 n.6 (1950). 


\section{The Naturalization Power}

The power "to establish an uniform Rule of Naturalization"33 is sometimes suggested, together with sovereignty, as a source of power over immigration. ${ }^{34}$ Recent expulsion cases have found significance in the fact that the aliens before the Court had not become naturalized. These cases hint that failure to attain citizenship can justify banishment. ${ }^{35}$ In times closer to the adoption of the Constitution, however, the existence of permanent residents who were not naturalized was accepted. ${ }^{36}$ Thus, in 1799, Judge Iredell implied that the right to remain depended only upon prescribed behavior for a limited probationary period, ${ }^{37}$ after which the resident noncitizen would not even have been subject to the Alien Act of $1798 .^{38}$

A finding that the naturalization power affords no affirmative basis for expulsion would not empty the power of content. Rights and privileges attend naturalization; for example, the vote and the passport. The distinction between resident citizens and resident aliens is meaningful, therefore, without assuming an unlimited power to expel the latter without regard to the duration of their stay.

\section{The War Power}

In time of war all powers of the federal government, including authority over resident aliens, are necessarily augmented. ${ }^{39}$ Expulsion under the war power began with the Enemy Alien Act of $1798,{ }^{40}$ which remains today substantially unchanged. ${ }^{41}$ The power to remove under this act, while exercisable

33. U.S. Const. art. I, § 8, cl. 4.

34. See Harisiades v. Shaughnessy, 342 U.S. 580, 599 (1952) (dissenting opinion of Douglas, J.) ; Hines v. Davidowitz, 312 U.S. 52, 66 (1.941) (dictum).

35. E.g., Harisiades v. Shaughnessy, 342 U.S. 580,585 (1952). Se'e also Carlson v. Landon, 342 U.S. 524, 537 (1952). This rationale was first proposed in 1893. Fong Yue Ting v. United States, 149 U.S. 698,707 (1893).

36. See The Naturalization Act of 1790, ch. 3, 1 Stat. 103.

37. [If] during a limited time ... [an alien] has behaved as a man of a good moral character, attached to the principles of the constitution of the United States, and well disposed to the good order and happiness of the same. ... he is no object of the alien law to which the objection is applied, because he is not a person whom the president is empowered to remove, for such a person could not be deemed dangerous to the peace and safety of the United States, nor could there be reasonable grounds to suspect such a man of being concerned in any treasonable or secret machinations against the government, in which cases alone the removal of any alien friend is authorized.

Case of Fries, 9 Fed. Cas. 826, 834-35 (No. 5126) (C.C.D. Pa. 1799) (charge to jury).

38. Ch. 58,1 Stat. 570.

39. See Johnson v. Eisentrager, 339 U.S. 763, 768-69 (1950) (recounting traditional hostility to alien in time of war). See also Brown v. United States, 12 U.S. (8 Cranch.) 110 (1814).

40. Ch. 66,1 Stat. 577. It is not to be confused with the Alien Act of 1798 , ch. 58, 1 Stat. 570.

41. See Rev. Stat. $\$ \S 4067-70$ (1875), as amended, 50 U.S.C. $\S \S 21-24$ (1952). 
absent actual hostilities, ${ }^{42}$ is limited to periods of war or the imminent threat of war, and cannot be employed once the state of war is officially ended. ${ }^{43}$

A fundamental distinction therefore exists between removal under the Enemy Alien Act and peacetime expulsion. ${ }^{44}$ But the careful restriction of warpower deportation statutes to current defense needs has not always been attempted. For example, the Alien Act of 1798,45 which authorized the removal of resident aliens of neutral and even friendly nations, was supported by its proponents on the ground that it was designed to cope with future hostilities. ${ }^{46}$ The Act of May 10, 1920, ${ }^{47}$ presented the converse of this situation. Not part of the general immigration law, ${ }^{48}$ the act was a direct result of World War I. It applied only to interned aliens, and aliens who had been, or who might thereafter be, convicted of certain wartime crimes. Its purpose, moreover, was to sanction deportation under the Enemy Alien Act even after the ratification of the then-pending peace treaty. ${ }^{40}$

The validity of this act was questioned in Mahler $v . E b y, 50$ a habeas corpus proceeding brought by a group of aliens who had been convicted of violating the Espionage and Selective Service Acts. Their principal contention was that the statutory phrase, "undesirable resident," a finding of which constituted a ground for expulsion, was too vague a standard to satisfy the due process requirements for a delegation of power to the executive. ${ }^{51}$ In remanding the case, the Court did not adopt this approach, however. It construed the clause as incorporating the basic exclusion policies of existing and past statutes and held that, although the convictions might justify a finding that petitioners were "undesirable residents," the expulsion orders were invalid because the Secretary of Labor had made no express finding to that effect. ${ }^{52}$

42. Ludecke v. Watkins, 335 U.S. 160, 166-70 (1948).

43. United States ex rel. Jaegeler v. Carusi, 342 U.S. 347 (1952).

44. Compare Citizens Protective League v. Clark, 155 F.2d 290, 293 (D.C. Cir. 1946), with United States $e x$ rel. Jaegeler v. Carusi, supra note 43.

45. Ch. $58,1$. Stat. 570 .

46. See Case of Fries, 9 Fed. Cas. 826, 832-35 (No. 5126) (C.C.D. Pa. 1799) (charge to jury) ; Fong Yue Ting v. United States, 149 U.S. 698, 747 (1893) (dissenting opinion of Field, J.). The constitutionality of the Alien Act of 1798 has long been questioned. See Ludecke v. Watkins, 335 U.S. 160, 171 n.18 (1948) (dictum); United States c.r rel. Turner v. Williams, 194 U.S. 279, 294-95 (1904) (dictum); Chae Chan Ping v. United States, 130 U.S. 581, 610-11 (1889) (dictum).

47. Ch. 174, 41 Stat. 593.

48. The provisions of the 1920 act were, however, included in the recodification of the Immigration and Nationality Act of 1952, $\$ 241$ (a) (17), 66 Stat. 207,8 U.S.C. $\S 1251$ (a) (17) (1952).

49. See United States ex rel. Eichenlaub v. Shatghnessy, 338 U.S. 521,532 (1950), where it was also noted that "the Government refers to this [the Enemy Alien] Act in its argument in interpreting the Act of May 10, 1920, as in pari materia. . . " Id. at 526 n.10. See also Ludecke v. Watkins, 335 U.S. 160, 167-68 n.12, 179-81 (1948).

50. 264 U.S. 32 (1924).

51. See $i d$, at 37.

52. Id. at 40-44. It is interesting to note that the lack of such findings had not been assigned as error. $I d$. at 45 . The Court also noted that had the aliens been mere internees 
The 1920 act, with which Mahler deals, was significant primarily because it was the first retroactive addition of grounds for expulsion not expressly related to a preexisting ground of exclusion. ${ }^{53}$ But to justify the legislation, the existence of an implied restriction imposed at the time of entry, that the immigrant will not engage in conduct harmful to the nation during time of war, might have been suggested. ${ }^{54}$

Decided solely as a matter of statutory construction, Mahler cannot be understood to resolve the question of the status of the resident alien under either the war power or the general immigration laws. ${ }^{55}$ No doubt the resident alien is subject to the war power even after war has come to an end. But, while the courts are reluctant to review congressional determinations of what constitutes a threat to national security justifying the use of the war power, ${ }^{56}$ it is submitted that when an alien's right to remain is at stake, a court may justifiably require that regulations under that power be reasonably related to the danger feared, and that the individual alien be given an opportunity to demonstrate that he is not a member of the dangerous group. ${ }^{57}$ The nature

instead of convicted saboteurs, a finding that they were "undesirable residents" might not have been justified. Id. at 42 .

53. See text at notes 205-54 infra for an analysis of the legislative history of exclusion and expulsion.

54. Compare Case of Fries, 9 Fed. Cas. 826, 834-35 (No. 5126) (C.C.D. Pa. 1799) (Alien Act of 1798).

55. Admittedly, Mahler has been construed as settling any possible constitutional issue. See United States $e x$ rcl. Eichenlaub v. Shaughnessy, 338 U.S. 521,529 \& n.15 (1950). But the relators in Eichenlaub did not raise a constitutional issue, relying instead on the contention that the 1920 act did not apply to them since they had been naturalized citizens at the time of their convictions, Brief for Relator, pp. 9-23. Thus the language regarding the extent of congressional power over aliens in Eichenlaub can be regarded as dicta or, at best, hastily considered. Yet Eichenlaub has since been cited to uphold the constitutionality of various exercises of power over aliens. See, e.g., Mulcahey v. Catalanotte, 353 U.S. 692, 694 n.5 (1957) (permanent resident convicted of illicit traffic in narcotics in 1925 deportable under 1952 immigration and naturalization act) ; Rabang v. Boyd, 353 U.S. 427, 433 (1957) (permanent resident since 1930 deportable due to violation of narcotic laws in 1951); Carison v. Landon, 342 U.S. 524, 534 n.18 (1952) (expulsion of resident alien Communists).

56. Cf. Hirabayashi v. United States, 320 U.S. 81, $93-94$ (1943).

57. See Rostow, The Japanese-American Cases-A Disaster, 54 YALE L.J. 489 (1945). Should Congress seek to justify legislation such as that involved in Galvan v. Press, 347 U.S. 522 (1954), under the war power, this substantive due process standard would work as follows: if the Court assumes that Congress intended to deport all those who had ever been Communists regardless of whether they now retain enough of the Party's beliefs to constitute a danger, then the act cannot be justified as a regulation of aliens under the war power and becomes one prescribing punishment for past activities, to be tested against the standards of cruel and unusual punishment, the prohibition against ex post facto laws, and other safeguards. If, on the other hand, the Court assumes that Congress intended to authorize deportation of only those aliens whose presence constitutes a present danger, then the irrebuttable presumption that an alien who was once a Communist remains a substantial threat to national security is invalid when applied to an alien who can show that he, together with others in his precise situation, 
of the war power, moreover, would seem to require the employment of the least amount of power appropriate to the ends sought.". Thus, the source of congressional power to expel resident aliens in peacetime would ordinarily be discovered elsewhere.

\section{Sovereignty}

The highest barrier to a fresh consideration of the long-term resident alien's status is the doctrine that congressional power over aliens is inherent in sovereignty. Thus regarded, the power is extraconstitutional, and is measured only by the principles of international law. Given this view, it is pointless to discuss possible substantive limits to the power, since the traditional rule of international law is that the expelled alien's only remedy is the diplomatic protest of his native state. ${ }^{50}$ It is the purpose of the immediate discussion, therefore, to establish that the concept of sovereignty as developed in the early cases did not concern the power of the federal governmnt over the domestic resident alien population, but rather a power of the federal government in the field of international relations-the power to remove a citizen of another country over the country's objections. ${ }^{60}$ These cases upheld the power to exclude or eject Chinese laborers, treaty rights notwithstanding. They did not answer the question of the rights of the individual resident alien under our domestic constitutional law. ${ }^{\mathbf{6 1}}$

When an alien claims to be entitled to enter or remain because of rights created by treaty with his native country, as did the Chinese laborers in the landmark cases, his rights may properly be determined on the basis of international law. The issues presented are clearly within the field of foreign re-

does not pose such a threat. Using either approach, the results of Galvan could be avoided.

Substantive due process limits were recently imposed on the war power in Trop v. Dulles, 356 U.S. 86 (1958) (expatriation case). Mr. Justice Brennan, concurring, id. at 105-14, states the reasoning behind the result most clearly.

58. Cf. United States ex rel. Toth v. Quarles, 350 U.S. 11, 23 (1955). Admittedly, the conception of what can be done under the war power has expanded in recent years. See, e.g., Act of June 21, 1941, 55 Stat. 252, 22 U.S.C. $\$ 233$ (1952), making the restrictions which then existed on the rights of both citizens and aliens to leave the United States in time of war applicable in periods of "national emergency." Regulations under this act were upheld in two exclusion cases. Shaughnessy v. United States $e x$ rcl. Mezei, 345 U.S. 206 (1953) ; United States ex rel. Knauff v. Shaughnessy, 338 U.S. 537 (1950). The harsh results reached in these cases have been severely criticized. See, c.g., Bullitt, supra note 11 , at $210-13$ (discussing $M e z e i$ ).

As to power over citizens under the war powers, see $E x$ parte Endo, 323 U.S. 283 (1944) ; Korematsu v. United States, 323 U.S. 214 (1944) ; Hirabayashi v. United States, 320 U.S. 81 (1943).

59. See Briggs, Law of Nations 536-38 and authorities cited (2d ed. 1952).

60. See Boudin, supra note 11, at 473-74; text at notes 79-81, 87-88 infra.

61. "The supposedly absolute power is only absolute with respect to outside powers or foreigners not within our territory. It is not absolute with respect to the power itself, and its exercise must always be justified in our courts under the Constitution." Boudin, supra note 11 , at 461 . 
lations and the treaty power. ${ }^{62}$ On the other hand, international law alone cannot dispose of the rights of the lawful resident alien who claims no protection by virtue of his nativity. His rights must be tested with reference to the Constitution.

From the first, the doctrine of inherent sovereignty concerned the ability of the United States to function as a nation in international affairs. The powers necessary to carrying on international relations were implied from the national sovereignty when not expressly delegated by the Constitution. ${ }^{63}$ As immigration necessarily affects both foreign commerce and foreign relations, early state statutes regulating the entrance of aliens were held invalid, ${ }^{64}$ even though Congress had not yet legislated on the subject. ${ }^{65}$

Subsequently, Congress' first attempt to exercise its power over immigration, the enactment of a "head tax" on immigrants, ${ }^{66}$ was upheld as a regulation of foreign commerce in the Head Money Cases. ${ }^{67}$ The Court made this clear in disposing of the argument that the statute was invalid under the tax power: "[T] he power exercised in this instance is not the taxing power. The burden imposed on the ship-owner by this statute is the mere incident of the regulation of commerce- of that branch of foreign commerce which is involved in immigration." 68

The contention that the act violated existing treaties was also rejected, on the ground that the enforcement of international agreements was beyond the competence of a domestic court which was bound by the last utterance of its own sovereign on the subject. ${ }^{60}$ This holding affords a focus for the first exclusion and ejection cases, which soon followed.

\section{The Yellow Hordes Theory of Exclusion}

The Act of May 6, 1882, ${ }^{70}$ excluding Chinese laborers, did not apply to those then within the United States. To facilitate their reentry, certificates of identity were prescribed. These certificates were later made the exclusive means of establishing the right of Chinese laborers to reenter. ${ }^{71}$ The Act of

62. With respect to the treaty power as a source of immigration power, see text at notes $139-45$ infra.

63. See, e.g., Schooner Exchange v. MoFadden, 11. U.S. (7 Cranch) 116, 136 (1812).

64. Chy Lung v. Freeman, 92 U.S. 275, 280 (1876). Henderson v. Mayor of the City of New York, 92 U.S. 259, 273 (1876).

65. In the case of health and quarantine laws, state regulatory power exists at least until Congress has acted. See Compagnie Francaise de Navigation a Vapeur v. Board of Health, 186 U.S. 380, 391 (1902).

66. Act of Aug. 3, 1882, ch. 376, 22 Stat. 214 (1883).

67. Edye v. Robertson, 112 U.S. 580, 590-91, 593-94 (1884).

68. Id. at 595.

69. Id. at 597-99.

70. Ch. 126, 22 Stat. 58.

71. Act of July 5,1884 , ch. $220, \S 5,23$ Stat. 115,116 . This act was held inapplicable to those who had been residents at the time of the 1880 treaty with China, but had departed prior to the enactment of the Exclusion Act of 1882 and remained outside of the 
Oct. $1,1888,72$ finally prohibited entry to Chinese laborers, certificates of identity notwithstanding. The validity of this act was challenged in Chae Chan Ping v. United States. ${ }^{73}$

The major constitutional questions raised in this case were whether any nation can exclude foreigners, and whether the treaties, pursuant to which the prior acts providing for certificates of identity were enacted, gave those before the Court a vested right to reenter ${ }^{74}$ Although counsel for the aliens attempted to raise a fifth amendment point, ${ }^{7 \bar{\alpha}}$ the Court treated the case as though the only issues were the exclusion power under international law, and the right of the United States to abrogate treaty privileges.

Mr. Justice Field, writing for a unanimous court, first outlined the treaties between the United States and China concerning immigration, ${ }^{70}$ and, with regard to the Chinese laborers covered by these treaties, observed:

[T] hey remained strangers in the land, residing apart by themselves, and adhering to the customs and usages of their own country. It seemed impossible for them to assimilate with our people or to make any change in their habits or modes of living. As they grew in numbers each year the people of the coast saw, or believed they saw, . . . great danger that at no distant day that portion of our country would be overrun by them unless prompt action was taken to restrict their immigration. ${ }^{77}$

This is the genesis of the self-preservation theory as applied to the regulation of immigration - the theory of nonassimilable yellow hordes.

With respect to the power to abrogate treaty rights, the opinion closely followed the Head Money Cases. ${ }^{78}$ The issue thus narrowed to congressional power independent of any treaty restrictions, the opinion continued:

That the government of the United States, through the action of the legislative department, can exclude aliens from its territory is a proposition which we do not think open to controversy. Jurisdiction over its own territory to that extent is an incident of every independent nation. It is a part of independence. If it could not exclude aliens it would be to that extent subject to the control of another power. ${ }^{79}$

Since congressional power to exclude under the foreign commerce power had already been recognized, discussion of the power of independent nations must have been intended to serve some other purpose. It seems clear that Mr. Justice Field was simply answering counsel's assertion that no nation can

United States until after the enactment of the 1884 act. Chew Heong v. United States, 112 U.S. 536 (1884).

72. Ch. 1064,25 Stat. 504.

73. (The Chinese Exclusion Case) 130 U.S. 581 (1889). For an account of the enforcement difficulties that led to progressive tightening of the regulations, see id. at $598-99$.

74. See Brief for Appellant, 32 L. Ed. 1069.

75. See 130 U.S. at 584, 586 (argument for appellant).

76. Id. at 590-95.

77. Id. at 595 .

78. Id. at 600 .

79. Id. at 603-04. 
exclude under international $1 a w^{80}$ for the next paragraph of the opinion turned to the constitutional delegation of federal power, itemizing some of the major provisions of article I, section 8 , primarily the war, treaty, foreign commerce, and naturalization powers, as attributes of sovereignty. ${ }^{81}$ To this point, then, there is nothing in the opinion to suggest that Congress' power to exclude rests on any ground other than the authority delegated by the Constitution. In what followed, however, the specific basis upon which the act was upheld became blurred. The Court, likening Asiatic immigration to imminent aggression, invoked war-power concepts to uphold peacetime exclusion. ${ }^{82}$

But the question of power to exclude in peacetime had already been implicitly settled, since the power to regulate immigration as part of foreign commerce necessarily encompassed the power to exclude undesirables, such as criminals, paupers, and diseased persons, categories already specifically recognized..$^{83}$ The 1888 act, however, was based on race rather than any personal defect. It was not unnatural, therefore, particularly in view of the prevailing prejudice on the Pacific coast towards resident Chinese, ${ }^{84}$ that the Court endorsed the yellow-peril theory upon which the act was predicated. ${ }^{85}$

Admittedly, quasi-war concepts were later uncritically applied to ejection. As applied in Chae Chan Ping, however, they did not play a crucial part, for exclusion clearly deals with the external, political relations of the United States with other nations. ${ }^{80}$ It would seem that a meaningful line could be drawn between the treatment of aliens outside the country and those properly within its borders. Nevertheless, since Chae Chan Ping first introduced the confusion between the war and foreign commerce powers, there has been little attempt to distinguish between them even in cases dealing with the status of permanent resident aliens.

In any event, the conclusion of the opinion makes it clear that whatever the power supporting the exclusion, it was constitutionally delegated and did not arise, extraconstitutionally, from the fact of sovereignty:

80. See Brief for Appellant, 32 L. Ed. 1069. But cf. Supplementary Brief for Appellant, 130 U.S. at 585 .

81. 130 U.S. at 604.

82. Id. at 606 . Thus, the first exclusion cases were founded, in part at least, on a presumption that Asiatic persons were nonassimilable as a matter of law, a fact which has been disproven by subsequent history. See PREsIDENT's Comm'n REP. 96.

83. See Edye v. Robertson (Head Money Cases), 112 U.S. 580, $590-91$ (1884).

84. See generally Yankwich, Social Attitudes as Reflected in Early California Law, 10 Hastings L.J. 250, 257-64 (1959).

85. As to the duty of the courts to accept the racism, xenophobia, or religious intolerance of Cangress, see Mr. Justice Frankfurter, concurring, in Harisiades v. Shaughnessy, 342 U.S. 580, 597 (1952). Congress may still be unduly race-conscious. See S. REP. No. 1515, 81st Cong., 2d Sess. 7-12 (1950). See also Prestdent's CoMm'N Rep. 91-94.

86. By explicitly equating the status of reentering Chinese laborers with those seeking initial entry, the Court in Chae Chan Ping laid the basis for the doctrine of reentry. But, since those involved in the case were relying on their foreign nationality, they were in a different category from modern immigrants. A critique of the reentry doctrine, however, is beyond the scope of the present inquiry. 
The power of exclusion of foreigners being an incident of sovereignty belonging to the government of the United States, as a part of those sovereign powers delegated by the Constitution, the right to its exercise ... cannot be granted away or restrained on behalf of anyone. The powers of government are delegated in trust to the United States, and are incapable of transfer to any other parties. They cannot be abandoned or surrendered. ...87

Thus, the power to exclude could not be restricted by treaty so as to hinder the protection of the people who granted it. Clearly, then, the discussion concerning sovereignty in the opinion related not to the question of the extent of constitutional power over the people, but rather to the power under international law with respect to China.

A further point must be noted with regard to Chae Chan Ping. It was stated that a government which feels dissatisfied with the treatment accorded its subjects may seek redress through diplomatic channels. ${ }^{88}$ Since the case involved parties who were asserting rights as subjects of a foreign nation protected by treaty, the theory had relevance to the issues presented. But it is not applicable to cases involving permanent residents admitted solely as the result of compliance with domestic immigration laws.

\section{The Conditional Entry Theory of Expulsion}

The application of the principles of exclusion to cases of expulsion may be traced to a dictum of Mr. Justice Gray in Nishimura Ekiu v. United States, ${ }^{80}$ a case involving the public charge clause of the exclusion provisions of the Act of March 3, $1891 .^{90}$

It is an accepted maxim of international law, that every sovereign nation has power, as inherent in sovereignty, and essential to self-preservation, to forbid the entrance of foreigners within its dominions, or to admit them only in such cases and upon such conditions as it may sce fit. . . . In the United States this power is vested in the national government, to which the Constitution has committed the entire control of international relations. . . . It . . . may be exercised either through treaties ... or through statutes .... [T] he Constitution has conferred power [upon Congress] to regulate foreign commerce with foreign nations, including .... the bringing of persons into the ports of the United States; to establish a uniform rule of naturalization; [and] to declare war..$^{91}$

This is the first suggestion of a conditional entry theory of expulsion: a theory that the power to expel is implied from the power to exclude, and is exercised by imposing conditions upon the right to enter. This power was recognized both as inherent in sovereignty under international law and as one

87. 130 U.S. at 609. (Emphasis added.)

88. Id. at 606 .

89. 142 U.S. 651 (1892).

90. Ch. 551, 26 Stat. 1084.

91. 142 U.S. at 659 . (Emphasis added.) 
delegated to the federal government by the Constitution. The conditional-entry concept has been adhered to, at least in theory, ever since. ${ }^{92}$ The scope of the immigration power implied in Ekiu is illuminating: first, immigration may be regulated by exercise of the treaty power; otherwise it is regulated by Congress, which has the power to regulate the coming of persons into our ports. Once an alien has obtained entrance, he is still subject to regulation with respect to his naturalization, and he may also become subject to the war powers of Congress. Certainly nothing more is suggested by the Head Money Cases or Chae Chan Ping, cited by the Court in support of the quoted passage. ${ }^{03}$

This reading of Ekiu may cast light on the subsequent ejection case of Fong $Y$ ue Ting $v$. United States, ${ }^{94}$ of which Gray was again the author. He did not believe that his views in Fong Yue Ting were inconsistent with Ekin, although three dissenters disagreed. An analysis of the divergent views of Fong Yue Ting will disclose its true meaning.

\section{The Manner and Burden of Proof of Lazeful Entry}

Fong Yue Ting involved the validity of section 6 of the Act of May 5, 1892,95 which provided for the procurement of certificates of residence as a means of identifying which Chinese were in the United States legally after the absolute exclusion of Chinese immigrants. Failure to have a certificate after a specific date subjected all Chinese laborers to ejection. The burden of proving lawful entrance was shifted to all resident Chinese laborers. The testimony of "at least one credible white witness" was an additional requirement. ${ }^{96}$ The

92. See, e.g., Lapina v. Williams, 232 U.S. 78, 88 (1914) ; Lem Moon Sing v. United States, 158 U.S. 538, 542-43 (1895) ; Cunard S.S. Co. v. Mellon, 262 U.S. 100, 125 (1923) (dictum). See also text at note 160 infra.

93. 142 U.S. at 659.

The main issue in Ekiu was the delegation of factfinding power to officers of the Executive branch. In upholding this, the Court seemed to imply that the entrant alien had a different status than the lawful resident. $I d$. at 660 . The opinion relied on Den $e x$ dem. Murray v. Hoboken Land \& Improvement Co., 59 UIS. (18 How.) 272 (1855), involving summary procedures in assessing taxes, and Hilton v. Merritt, 110 U.S. 97 (18S4), involving the summary procedure authorized in dealing with imports.

The importance of achieving lawful admittance was further emphasized by the opinion's careful note of the fact that while Ekiu had been taken from the ship upon which she had arrived, her physical entry did not change her status or affect her right to remain, for she was "in the same position, so far as regarded her right to land in the United States, as if she never had been removed from the steamship." 142 U.S. at 661 . This view has been followed ever since. See, e.g., Kaplan v. Tod, 267 U.S. 228 (1925); Zartarian v. Billings, 204 USS. 170 (1907); cf. Rogers v. Quan, 357 U.S. 193 (1958); Leng May Ma v. Barber, 357 U.S. 185 (1958).

94. 149 U.S. 698 (1893).

95. Ch. $60, \S 6,27$ Stat. 25 .

96. Ibid. The view that Chinese were not credible witnesses did not enjoy unanimous acceptance. See Quock Ting v. United States, 140 U.S. 417, 423-24 (1891) (dissenting opinion). 
issue framed by this statute was whether Congress could eject a resident who could not prove his status by the testimony of a white witness simply by creating a conclusive presumption of unlawful entry. Viewed in this manner, the import of both the majority and minority opinions is more readily determined. The minority felt that lawfully admitted resident aliens were being ejected, ${ }^{97}$ while the majority was willing to uphold the provision as a rule of evidence in exclusion cases justified by the difficulties of proof of unlawful entry and the unreliability of Chinese witnesses..$^{98}$

Despite the narrow issue actually involved, the act was attacked on broad grounds-that permanently domiciled residents are de facto citizens; that the act, as applied, constituted banishment; that Chinese laborers enjoyed special treaty immunities from ejection; that the act violated procedural due process; that no such peacetime power was delegated to Congress; and that there were no nondelegated sovereign powers. ${ }^{99}$

The Government contended that the cases were indistinguishable from Chae Chan Ping, that shifting of the burden of proof was proper, and that a nation has unlimited power to regulate and suspend the residence of aliens within its borders. The last assertion was based entirely on international law authorities. ${ }^{100}$

With both sides arguing the existence or nonexistence of extraconstitutional power, it is not surprising that the majority opinion considered the doctrine of inherent sovereignty. Moreover, since petitioners relied on their treaty rights as Chinese nationals and also claimed to be de facto citizens who were being banished, it was relevant to consider what their rights were under international law. The sovereignty approach was also relevant to meet the arguments of the dissenting justices, whose opinions rested in part on an asserted lack of any power to expel friendly aliens under international law. ${ }^{101}$

Mr. Justice Gray opened the majority opinion by quoting with approval from the previously analyzed portions of the opinions in Ekiu and Chac Chan Ping dealing with the sovereign rights of nations with respect to immigrants. ${ }^{102}$ Thus, he must have considered what was countenanced in Fong Yue Ting to be a legitimate extension of the principles that he had enunciated in Ekiu. Since the parties before the Court had not proved by clear and con-

97. See 149 U.S. at 733, 746, 762 (dissenting opinions of Brewer and Field, JJ., and Fuller, C.J.). Mr. Justice Harlan did not participate in the decision, as he was in Europe at the time. His views, however, were apparently in accord with the dissenting justices. Mr. Justice Field tried, unsuccessfully, to get a fifth vote for the dissenting views in Fong Yue Ting after the death of Mr. Justice Blatchford. See Westin, Stephen J. Ficld and the Headnote to O'Neil v. Vermont: A Snapshot of the Fuller Court At Work, 67 YaLE. L.J. 363, 380-83 (1958).

98. 149 U.S. at $729-30$.

99. Brief for Petitioners, 37 L. Ed. 908-09.

100. Brief for Respondent, 37 L. Ed. 910.

101. See particularly the opinion of Mr. Justice Field, 149 U.S. at 756-57.

102. 149 U.S. at 705. For the relevant portions of the earlier opinions see quotations in text at notes 87,91 supra. 
vincing evidence that they were lawful residents, and that the presumption of unlawful entry created by lack of a certificate operated contrary to fact, Gray felt free to judge the reasonableness of the statute as an implementation of exclusion policies. Nor are the prior opinions necessarily inconsistent with the assertion that "the right of a nation to expel or deport foreigners, who have not been naturalized or taken any steps towards becoming citizens of the country, rests upon the same grounds, and is as absolute and unqualified as the right to prohibit and prevent their entrance into the country."103 Viewing the case as one of ejection rather than of banishment, this merely equates the status of unlawful residents to that of immigrants seeking admission, a development clearly foreshadowed in Ekiu. ${ }^{104}$

The applicability of this equation was not so self-evident to $\mathrm{Mr}$. Chief Justice Fuller, Mr. Justice Brewer, and Mr. Justice Field, who, assuming that the aliens in this case were lawful residents, were deciding whether congressional regulatory power could be applied at all to expel these who could not meet the statute's "evidentiary" requirements. ${ }^{105}$ In his short dissent, the Chief Justice met the issue so framed most squarely, arguing that expulsion could not be treated identically with exclusion since "limitations exist or are imposed upon the deprivation of that which has been lawfully acquired."108 Further, he said, the power to deal arbitrarily with persons lawfully within the country cannot be derived from "any delegated power, or power implied therefrom, or . . . supposed inherent sovereignty. . . ."107 It is a natural tendency to read the majority opinion as asserting the contrary to these views so vigorously espoused by the dissenting justices. But a careful reading of Gray's argument shows that whatever the rights of a sovereign under international law, congressional power over resident aliens was regarded as constitutionally delegated, and therefore, by implication, constitutionally limited.

Admittedly, after mustering debatable authority in support of the powers of a sovereign nation to expel, ${ }^{108}$ the majority opinion stated:

The right to exclude or expel all aliens, or any class of aliens, absolutely or upon certain conditions, in war or in peace, being an inherent and inalienable right of every sovereign and independent nation, essential to

103. 149 U.S. at 707.

104. Mr. Justice Gray's language is admittedly broader than the interpretation offered here. Nevertheless, the facts of Fong Yue Ting did not require the assertion of the existence of unlimited congressional power. Arguably, Gray was speaking only of an unlimited power to expel the presumably illegally admitted aliens then before the Court. Any further assertion of power can be regarded as dictum.

105. 149 U.S. at 737, 738 (Brewer, J.) ; id. at 746, 750 (Field, J.) ; id. at 762 (Fuller, C.J.).

106. Ibid.

107. Ibid.

108. The authority consisted of two diplomatic dispatches, general quotations from four international law treatises, and two English decisions. 149 U.S. at 707-11. The dispatches had been relied on by Mr. Justice Field to support the power to exclude in Chae Chan Ping, 130 U.S. at 607. It is significant that he did not regard them as relevant 
its safety, its independence and its welfare, the question now before the court is whether the manner in which Congress has exercised this right in sections 6 and 7 of the Act of 1892 is consistent with the Constitution. 109

This statement might be interpreted as the final answer to the objections raised by the dissenting opinions, leaving open only the procedural due process issue. But instead of resting the decision on the power of sovereign nations to exclude and expel, the next paragraph turned to the question of the constitutional delegation of sovereign powers, discussing it in substantially the words already quoted from Ekiu. ${ }^{110}$ Unless this portion of the opinion is to be treated as meaningless, it is apparent that the power to regulate resident aliens was not predicated on nondelegated sovereign power. ${ }^{111}$ Given that only delegated power was relied on, the subsequent portion of the opinion can be analyzed in a manner that lends no support to the recent banishment cases. The opinion continued :

The power to exclude or to expel aliens, being a power affecting international relations, is vested in the political departments of the govern-

when the power to expel was at issue. Field also disagreed with Gray's interpretation of the treatises, and it would seem from the opinions that their meaning is at least debatable. See 149 U.S. at 756-58.

Neither of the English decisions support the conclusions for which they are cited if Mr. Justice Gray is to be understood as intending to settle the question of the status of all lawful American residents. The first, In re Adam, 1 Moore P.C. 460, 12 Eng. Rep. 889 (P.C. 1837), involved the power to eject, from an island conquered from France, a friendly alien who had been a long-term resident, "but who had not, as required by the French law, obtained from the colonial government formal and express authority to establish a domicil there." 149 U.S. at 710. In modern terms, he had never been lawfully admitted for permanent residence. An analogous factual situation is presented in United States v. Sui Joy, 240 Fed. 392 (9th Cir. 1917). When Fong Yue Ting was decided, no distinction was made at the time of entry between permanent and temporary residence. Moreover, immigrant Chinese laborers were virtually regarded as temporary residents as a matter of law, because of their presumed inability to assimilate. If this was Gray's view, the English decision may be considered in point.

The second case, Musgrove v. Chun Teeong Toy, [1891] A.C. 272, was an action by a Chinese immigrant against the collector of customs for the colony of Victoria for refusal to allow admittance. The action was disposed of on the question of whether "an alien has a legal right, enforceable by action, to enter British territory." 149 U.S. at 710-11. In fact, the British court had expressly said, "A right to deport aliens is not claimed in this case; it is a right to exclude them which is now in question." [1891] A.C. at 275 . Thus the case can scarcely be considered authority for the power to expel.

109. 149 U.S. at 711.

110. Id. at 711-12; see text at note 91 supra.

111. Thus, Professor Moore interpreted the rule just a few years after Fong Yue Ting: "The power to regulate immigration is an incident of the sovereign right to expel or exclude objectionable aliens. The exercise of the power in a particular country is governed by the constitution and laws. In the United States it belongs to the National Government as part of its power to regulate commerce." 4 MOORE, Digest of InternaTIONAL LAW 151 (1906). 
ment, and is to be regulated by treaty or by Act of Congress, and to be executed by the executive authority according to the regulations so established, except so far as the judicial department has been authorized by treaty or by statute, or is required by the paramount law of the Constitution, to intervene.

In Nishimura Ekiu's case, it was adjudged that . . . Congress might entrust the final determination of these facts [upon which the alien's right to land depend] to an executive officer, and that, if it did so, his order was due process of law ....

The power to exclude aliens and the power to expel them rest upon one foundation, are derived from one source, are supported by the same reasons, and are in truth but parts of one and the same power.

The power of Congress, therefore, to expel, like the power to exclude aliens ... . may be exercised entirely through the executive officers; or Congress may call in the aid of the judiciary to ascertain any contested facts on which an alien's right to be in the country has been made by Congress to depend.

Congress, having the right, as it may see fit, to expel aliens of a particular class, or to permit them to remain, has undoubtedly the right to provide a system of registration and identification of the members of that class within the country and to take all proper means to carry out the system which it provides. ${ }^{112}$

These five paragraphs demonstrate the basic reasoning employed to uphold the act involved. First, the powers relating to foreign relations have been delegated to the federal government, and immigration is regulated either by treaties or by acts of Congress. Second, the necessary fact finding can be delegated to the administrative officers enforcing the immigration laws. Third, as a part of this same power over immigration, the right to remain under the policies enunciated by Congress or treaty may likewise be conclusively determined by those officers. Finally, to effectuate this process, Congress can place the burden on the resident alien to establish his right to remain.

Read abstractly, some of the above language has been interpreted as upholding the absolute substantive power to expel. In particular, the third paragraph. is a favorite for supporting the "plenary" power of Congress over resident aliens. Read in context, however, the language was concerned with the procedural propriety of entrusting determinations of fact in expulsion cases to executive officers. The opinion may be said to recognize the plenary nature of the power of Congress, but only within the proper scope of the exercise of constitutionally delegated power. ${ }^{113}$

Substantive limits to congressional power might have been involved in up-

112. 149 U.S. at 713-14.

113. Compare Gibbons v. Ogden, 22 U.S. (9 Wheat.) 1, 86-87 (1824) (relating to interstate commerce) ; Veazie v. Moor, 55 U.S. (14 How.) 567, 573-74 (1852) (relating to foreign commerce). See generally Oceanic Steam Nav. Co. v. Stranahan, 214 U.S. $320,339-40$ (1909). 
holding the system of registration, and indeed there was a brief attempt in the opinion to show that the requirement of a white witness was reasonable. ${ }^{114}$ But the majority concentrated instead on the undesirable nature of the aliens before the Court. Thus, it was again stressed that Chinese residents were a class by themselves that could not or would not assimilate. ${ }^{115}$ The ever-increasing restriction upon their right to enter and remain in the United States was outlined, and the opinion concluded, particularly in view of the decision in Chae Chan Ping, that it was impossible to hold that petitioners had acquired, either by treaty, international law, or previous decisions of the Supreme Court, any exemption from the power of Congress over aliens. ${ }^{110}$

.Whether the scope of congressional power over presumably nonassimilable Chinese was considered broader than that of the power over other resident aliens is not entirely certain. ${ }^{117}$ But the majority's citation of Chy Lung v. Freeman, ${ }^{118}$ a case holding the states preempted in the immigration field, indicates that the source of congressional authority in the instant case was the power over foreign commerce, and not inherent sovereignty.

Gray disposed of the contention that the removal of petitioners amounted to banishment by arguing that it was "but a method of enforcing the return to his own country of an alien who has not complied with the conditions upon the performance of which the government of the nation, acting within its constitutional authority ... has determined that his continuing to reside here shall depend."119 Thus, the power to terminate the residence of aliens here was considered to rest upon conditional entry. But, the fact which disturbed the entire Court was that petitioners had not violated any conditions imposed at the time of their entrance, but only the terms of a subsequent act prescribing the manner of proof of their lawful entry. Only after pages upon pages discussing the shadowy concepts of inherent sovereignty and nonassimilability does the majority opinion finally reach the validity of the statute itself, and, by regarding its racially based presumptions as within the power to prescribe evidentiary rules, possible substantive issues were neatly avoided. ${ }^{120}$

Thus, the significance of Fong Yue Ting is that Congress has the power to eject resident aliens for conduct subsequent to entry. The conduct specifically involved was failure to meet the prescribed burden of proof of lawful entry. The power to raise presumptions, including conclusive presumptions, was subsequently extended to acts of substance (expellable acts) but Fong Yue Ting did not, as seems to have been assumed in recent cases, abrogate

114. 149 U.S. at 729-30.

115. Id. at 717 .

116. Id. at 716-24.

117. This question has been examined elsewhere and will not be pursued here. See

Boudin, The Settler Within Our Gates, 26 N.Y.U.L. Rev. 451, 455-74 (1951).

118. 92 U.S. 275 (1876), cited in 149 U.S. at 724.

119. Id. at 730 .

120. Id. at 729 . 
the need for Congress to find a rational nexus between proscribed conduct and the regulation of immigration before declaring an act expellable.

In concluding, Mr. Justice Gray again made clear that the statute was upheld as a valid exercise of constitutionally delegated congressional power. ${ }^{121}$ With the repetition of such statements concerning the opinion's rationale, it may seem surprising that it has been traditionally accepted as recognizing a dual source of power, one (foreign commerce) constitutionally defined and the other (sovereignty) extraconstitutional and undefinable. The reason, it is suggested, lies in the dissenting opinions, which refused to dispose of the constitutional status of lawful resident aliens by manipulating the manner of proof. ${ }^{122}$ But while it does not follow that prescribing conditions upon the right to remain was or is per se improper, it is nevertheless possible to agree with Chief Justice Fuller that the majority opinion, ambiguous as it is "contains within it the germs of the assertion of unlimited and arbitrary power, in general, incompatible with the immutable principles of justice, inconsistent with the nature of our government, and in conflict with the written Constitution by which that government was created and those principles secured."123

121. "[T]he judicial department cannot properly express an opinion upon the wisdom ... of the measures enacted by Congress in the exercise of the powers confided to it by the Constitution. ..." 149 U.S. at 731 .

122. See Boudin, supra note 117 , at $462-64$.

123. 149 U.S. at 764. It is beyond dispute that the opinions of Fong Yue Ting tend to mislead. The case could easily be understood to hold that resident aliens are, in effect, temporary residents as a matter of law, unless they are eligible to and do become citizens. The conclusion that Fong Yue Ting had been so interpreted by immigration officers is almost irresistible from the facts in United States v. Wong Kim Ark, 169 U.S. 649 (189S). Mr. Wong was born in the United States of parents who were non-diplomatic residents. He had previously departed from the United States and returned in 1890, subsequent to Chac Chan Ping but prior to Fong Yue Ting, and was admitted "upon the sole ground that he was a native-born citizen of the United States. . . [ [He] remained in the United States ... until the year 1894, when he again departed for China upon a temporary visit, and with the intention of returning . . .and did return . . . in . . . 1895 , and ... [was denied admittance] upon the sole ground that ... [he] was not a citizen of the United States." Id. at 651. Thus, it was not until after Fong Yue Ting, decided in 1893, that his citizenship was challenged. Previously, in Quock Ting v. United States, 140 U.S. 417 (1891), a sixteen-year-old Chinese entrant had been denied admittance solely on the ground that he failed to prove he was born in the United States. The assumption of both the Court and the Government at that time was, apparently, that a Chinese person born in the United States was a citizen. If it could be argued, however, that Chinese residents were to be taken as part of Chinese expansionism, and were to be considered as temporary residents, with no status or right to remain, it could be argued further that the children of such residents, who could not become naturalized, should not be considered within the meaning and intent of the constitutional definition of citizenship in the fourteenth amendment. Thus, Mr. Chief Justice Fuller, in his dissenting opinion in 'Wong Kim Ark, apparently acquiescing in Fong Yue Ting, concluded: "If children born in the United States were deemed presumptively and generally citizens [prior to the fourteenth amendment], this was not so when they were born of aliens whose residence was merely temporary, either in fact, or in point of law." 169 U.S. at 729. 
Expulsion and the Power to Punish

Wong Wing $v$. United States ${ }^{124}$ presented the question of the validity of section 4 of the Act of May 5, 1892,125 which had been noted but not passed on in Fong Yue Ting. ${ }^{120}$ It provided "that any such Chinese ... convicted and adjudged to be not lawfully entitled to be or remain in the United States shall be imprisoned at hard labor for a period of not exceeding one year and thereafter removed from the United States, as hereinbefore provided."127 This provision was held unconstitutional since it prescribed a criminal sanction without observance of the constitutional procedural prerequisites. ${ }^{128}$ What the opinion said in order to place this holding in context, however, is what is of present interest.

In reviewing the earlier opinions, the opinion in Wong Wing first summarized what had been stated in Fong Yue Ting. ${ }^{129}$ But further on in the opinion, the dicta went further than Fong Yue Ting, stating that the Chinese Exclusion Acts validly prescribed expulsion of both lawful and unlawful residents. ${ }^{130}$ That the question of the status of the lawfully admitted alien was presented in Fong Yue Ting is true, but the case did not dispose of that question, since the statute involved dealt only with the method of proof of lawful entry. Thus, the majority opinion in Wong Wing appeared to adopt the reading of Fong Yue Ting that had been so vigorously attacked by the dissenters in the earlier case-as authority for plenary congressional power over aliens. In a further restatement, however, this position was somewhat modified:

No limits can be put by the courts upon the power of Congress to protect, by summary methods, the country from the advent of aliens whose race or habits render them undesirable as citizens, or to expel such if they have already found their way into our land and unlawfully remain therein. ${ }^{131}$

This is the beginning of the idea that those who, subsequent to entry, display habits or characteristics which render them objectionable residents may be expelled. But to concede such power does not, as will be seen, mean that it is unlimited.

\section{The Status of the Illegal Entrant}

The only remaining pre-Harisiades immigration case which could be considered support for an inherent sovereignty basis of power over aliens, United

124. 163 U.S. 228 (1896).

125. Ch. $60, \S 4,27$ Stat. 25 .

126. 149 U.S. at 725-26.

127. Ch. $60, \$ 4,27$ Stat. 25.

128. 163 U.S. at 237.

129. Id. at 231 .

130. Id. at 234-35. These acts remained a separate sphere of legislation until their repeal by the Act of Dec. 17, 1943, ch. 344, 57 Stat. 600 .

131. 163 U.S. at 237; cf. United States v. Spector, 343 U.S. 169 (1952). 
States ex rel. Turner $v$. Williams, ${ }^{132}$ discloses upon analysis that no such theory was actually endorsed. Turner was a philosophical anarchist, who entered illegally for the purpose of a lecture tour. He was not seeking permanent residence, and was arrested only a few days after entrance. The case involved, therefore, the status of a temporary illegal resident. His counsel, however, attacked the proceedings upon the broad constitutional grounds that the act violated the first, fifth, and sixth amendments, and that there was no delegated power to exclude friendly aliens. ${ }^{133}$ To these contentions Mr. Chief Justice Fuller first replied, after restating the conditional entry theory of expulsion, that the expulsion of an illegal entrant is not a criminal proceeding. ${ }^{134} \mathrm{He}$ then observed that, whether congressional power rested on inherent sovereignty or on the power to regulate foreign commerce, the act before the Court could not be invalidated. ${ }^{135}$ This opinion must not be taken as an acceptance of a dual source of power over resident aliens; the Chief Justice was one of the Fong Yue Ting dissenters. Here, he was merely arguing that, whatever theory of power is adopted, the illegal entrant cannot object to his ejection. In any event, since the short-term, illegal entrant may properly be given the status of one at the border, the inherent sovereignty concept was as relevant to Turner as it had been to Chae Chan Ping. ${ }^{136}$ Thus, Turner cannot be legitimately interpreted as conceding to Congress unlimited power over all resident aliens.

\section{Executive Powers}

Attention has thus far been focused on legislative power. But in recent years confusion has arisen regarding the extent of executive power to regulate immigration. It is, therefore, essential to delineate the powers of the Executive in this field with precision.

\section{Delegation of Legislative Power}

Power delegated to enforce congressional policies can be readily distinguished from original executive power. The issue contested in Ekiu was whether Congress could delegate fact finding powers to executive officers. This delegation was upheld, and similar ones have repeatedly been sustained. ${ }^{137}$ The numerous instances in which the Court has reminded enforce-

132. 194 U.S. 279 (1904).

133. Id. at $285-89$.

134. Id. at 290 .

135. Ibid.

136. "[U]nder [the Constitution] the power to exclude has been determined to exist, [and] those who are excluded cannot assert the rights in general obtaining in a land to which they do not belong as citizens or otherwise." Id. at 292.

137. E.g., Mahler v. Eby, 264 U.S. 32, 40 (1924); The Japanese Immigrant Case (Yamataya v. Fisher), 189 U.S. 86 (1903).

As early as Case of Fries, 9 Fed. Cas. 826, 834 (No. 5126) (C.C.D. Pa. 1799), it was observed in a charge to the jury: "If this power is proper, it must be exercised by somebody. If from the nature of it, it could be exercised by so numerous a body as con- 
ment officers that they may not go beyond the policies enacted are adequate evidence that executive power over aliens is ordinarily legislative in origin. ${ }^{138}$

\section{The Treaty Power}

The theory of direct executive power over immigration probably stems from the cases which observed that the power to regulate immigration is vested in the political (nonjudicial) branches of the Government, and may be exercised by treaty as well as by act of Congress. ${ }^{139}$ Thus, besides exercising the power delegated to it by Congress, the Executive may also determine immigration policies to the extent that treaties are applicable.

But a treaty is not necessarily controlling, even on the points it covers. While a later treaty prevails over a prior statute, ${ }^{140}$ and a subsequent statute will be construed in conformity with prior treaty rights whenever possible, ${ }^{141}$ a subsequent inconsistent statute prevails over a prior treaty, ${ }^{142}$ and treaties are, when possible, construed in conformity with general immigration laws. ${ }^{143}$ Obviously, aside from cases involving a treaty which affects a particular alien or class of aliens, the treaty power cannot be relied upon to uphold the regulation of immigration. Indeed, those who enter pursuant to rights granted by some treaties are not classified as immigrants. ${ }^{144}$ Thus, in dealing with a permanent resident admitted in accordance with the general immigration laws,

gress, yet as congress are not constantly sitting, it ought not to be exercised by them alone. If they are not to exercise it, who so fit as the president? What interest can he have in abusing such an authority?"

138. See, e.g., Barber v. Gonzales, 347 U.S. 637 (1954); Fong Haw Tan v. Phelan, 333 U.S. 6 (1948) ; Kessler v. Strecker, 307 U.S. 22 (1939); Mahler v. Eby, 264 U.S. 32 (1924); Gegiow v. Uhl, 239 U.S. 3 (1915); Church of the Holy Trinity v. United States, 143 U.S. 457 (1892).

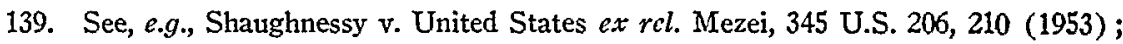
Mahler v. Eby, 264 U.S. 32, 40 (1924) ; The Japanese Immigrant Case, 189 U.S. 86, 100 (1903) ; Fok Yung Yo v. United States, 185 U.S. 296, 302 (1902); Nishimura Ekiu v. United States, 142 U.S. 651, 659 (1892). See also United States v. Lee Yen Tai, 185 U.S. 213,220 (1902).

140. See, e.g., United States v. Lee Yen Tai, 185 U.S. 213, 220 (1902) (dictum); Chae Chan Ping v. United States, 130 U.S. 581, 600 (1889) (dictum).

141. United States v. Gue Lim, 176 U.S. 459, 465 (1900); Lau Ow Bew v. United States, 144 U.S. 47, 62 (1892).

142. Reid v. Covert, 354 U.S. 1, 18 (1957) (dictum); Chae Chan Ping v. United States, 130 U.S. 581, 600 (1889) ; Botiller v. Dominguez, 130 U.S. 238 (1889); Whitney v. Robertson, 124 U.S. 190 (1888); Edye v. Robertson (Head Money Cases), 112 U.S. 580 (1884).

143. See The Japanese Immigrant Case, 189 U.S. 86 (1903).

144. Compare Cheung Sum Shee v. Nagle, 268 U.S. 336, 345 (1925) (holding that "an alien entitled to enter the United States 'solely to carry on trade' under an existing treaty of commerce and navigation is not an immigrant within the meaning of the [1924] Act, $\$ 3(6)$, and therefore is not absolutely excluded by $\S 13^{\prime \prime}$ ), with Chang Chan v. Nagle, 268 U.S. 346, 351 (1925) (noting that "this cause involves no claim of right granted or guaranteed by treaty"). 
rather than as a foreign national relying on treaty rights, no general claim to executive authority under the treaty power can be properly made..$^{145}$

\section{Foreign Relations}

The existence of a nonreviewable executive power to control aliens, based on the fact that foreign relations are involved, may also be suggested. ${ }^{\mathbf{1 4 6}}$ The role of the executive in immigration under the foreign relations power seems limited to dealing with the protests of the alien's native country. Obviously, the international consequences involved make immigration an area of executive concern. But when no diplomatic question is directly involved, the executive power in foreign relations seems irrelevant.

The modern theory of independent executive power seems directly traceable to United States $v$. Curtiss-Wright Export Corp. ${ }^{147}$ In overcoming the contention that a joint resolution, which in effect authorized the President, in his discretion, to declare the exportation of arms to certain countries a criminal act, was an unconstitutional delegation of legislative power, the Court stated that the rule that the federal government is one of limited, constitutionally delegated powers applied only to internal matters. ${ }^{148}$ While discussing the existence of extraconstitutional powers, Mr. Justice Sutherland stated: "[T] he power to expel undesirable aliens ... [exists] as inherently inseparable from the conception of nationality. ... [This] court . . . found the warrant for its conclusion [in this area] not in the provisions of the Constitution, but in the law of nations."

If the previous analysis of Fong Yue Ting is correct, then Mr. Justice Sutherland's assertion that it predicated the power to expel on extraconstitutional power is erroneous. ${ }^{150}$ In any event, the context in which he cited Fong Yue Ting shows that he did not intend to use the case in support of the principle he was ultimately seeking to establish-executive power without any constitutional basis. In the paragraph from which the preceding quotation is taken, he was dealing with the powers of the federal government as a whole, both legislative and executive. ${ }^{151}$ Only after identifying a separate category of powers, which allegedly inhere to a nation irrespective of any constitutional delegation, did Sutherland shift the focus of his opinion to his primary concern, the source of executive powers. ${ }^{152}$

145. See Keller v. United States, 213 U.S. 138, 147 (1909). It is, of course, possible that the Executive could make treaties which drastically affected the rights of resident aliens. But the treaty itself would have to conform to constitutional standards. Cf. Reid v. Covert, 354 U.S. 1, 17 (1957).

146. Cf. United States ex rel. Knauff v. Shaughnessy, 338 U.S. 537, 542 (1950).

147. 299 U.S. 304 (1936).

148. Id. at 315-16.

149. Id. at 318 .

150. See text at notes 95-123 supra.

151. See 299 U.S. at 315-16.

152. Id. at 319-20. The theory of inherent external powers presented in CurtissWright was a judicial expression of the same views Sutherland espoused in Constitu- 
The only principle of legitimate significance to the field of immigration that can be drawn from Curtiss-Wright, therefore, is that "the lack of a clause in the Constitution specifically empowering such action has never been held to render Congress impotent to deal as a sovereign with resident aliens."163 Nevertheless, in United States ex rel. Knauff v. Shaughnessy, ${ }^{15:}$ the entire rationale and theory of the opinion in Curtiss-Wright was applied in an exclusion case.

[T] here is no question of inappropriate delegation of legislative power involved here [under the $1941 \mathrm{Act}$, and the regulations enforcing it]. The exclusion of aliens is a fundamental act of sovereignty. The right to do so stems not alone from the legislative power but is inherent in the executive power to control the foreign affairs of the nation. United States v. Curtiss-Wright Export Corp. . . . ; Fong Yue Ting v. United Statcs .... When Congress prescribes a procedure concerning the admissibility of aliens, it is not dealing alone with a legislative power. It is implementing an inherent executive power. ${ }^{155}$

Since Knauff involved exclusion, which has a direct bearing on foreign relations, this statement may be justified, although neither Curtiss-Wright nor Fong Yue Ting dictated the extension of the principles they announced to the general regulation of aliens. If the statement is meant to apply only to cases involving so-called emergency powers, ${ }^{156}$ however, it need not be contested on principle. But the danger in resting exclusion cases on a so-called "inherent executive power" is that the theory might be transferred to cases of expulsion. ${ }^{157}$

It is important to realize, therefore, that there is nothing in the cases other than Knauff to justify a theory that the power to expel rests upon an inherent, undefined executive power. Curtiss-Wright did not purport to extend the inherent sovereignty theory beyond that espoused in Fong Yue Ting. And, in Harisiades, Fong Yue Ting was the sole judicial authority cited for the proposition that the power to expel rested on sovereignty. ${ }^{158}$

tional Power and World Afrairs (1919). Besides being based on unsupported historical premises, it is logically contradictory. See McLaughlin, The Scope of the Treaty Power in the United States, 42 MrNw. L. Rev. 709, 716-20 (1958).

153. Carlson v. Landon, 342 U.S. 524, 537 (1952) (citing Curtiss-Wright). This view ignores the fact that power over immigration had long been associated with the foreign commerce power. See Edye v. Robertson (Head Money Cases), 112 U.S. 580 (1884).

154. 338 U.S. 537 (1950).

155. Id. at 542 .

156. Knauff involved the Act of June 21, 1941, ch. 210, 55 Stat. 252, and executive regulations pursuant to it. These provisions of the act are now part of Immigration and Nationality Act of 1952, § 215, 66 Stat. 190, 8 U.S.C. $\$ 1185$ (1952).

157. Whenever a power to exclude has been found, the power to expel has followed close behind. Compare Chae Chan Ping v. United States, 130 U.S. 581 (1889), with Fong Yue Ting v. United States, 149 U.S. 698 (1893); and Lapina v. Williams, 232 U.S. 78 (1914).

158. Harisiades v. Shaughnessy, 342 U.S. 580, 587-88 (1952). 


\section{Substantive Limits to the Power To Expel}

Although the most recent case involving peacetime power over aliens that has thus far been examined in any detail is over fifty years old, the supposed support for the currently accepted theory of congressional power has been fully considered. Immediately prior to Harisiades, as a basis for the Immigration and Nationality Act of $1952,{ }^{159}$ Congress asserted:

The power of Congress to control immigration stems from the sovereign authority of the United States as a nation and from the constitutional power of Congress to regulate commerce with foreign nations. Every sovereign nation has power, inherent in sovereignty and essential to self-preservation, to forbid entrance of foreigners within its dominions, or to admit them only in such cases and upon such conditions as it may see fit to prescribe. Congress may exclude aliens altogether or prescribe terms and conditions upon which they may come into or remain in this country. 160

Basically, this view is predicated on, although a misapprehension of, three cases: Chae Chan Ping, Ekiu, and Fong Yue Ting. Originally, as has been seen, the power to regulate immigration was thought to be based on the foreign commerce ${ }^{101}$ and treaty powers. ${ }^{162}$ And although the broad sweep of the opinions in the three leading cases obscures the issue, ${ }^{163}$ none of them relies on sovereignty as the source of congressional authority. ${ }^{164}$ The use of the commerce power to justify peacetime regulation of immigration is, moreover, in accord with the analogous concept that carriage or movement of persons across state boundaries constitutes interstate commerce. ${ }^{165}$

But the more serious misconception expressed in the congressional expression of the basis of its power, however, is the apparent assumption that it may unconditionally impose conditions: the belief that since the power to exclude is absolute, the power to expel, which is implied from that power, must necessarily be equally unlimited. This approach may have enjoyed spotty acceptance in the last century, but constitutional thinking has evolved far be-

159. 66 Stat. 163,8 U.S.C. $\$ \$ 1101-503$ (1952).

160. H.R. REP. No. 1365, \&2d Cong., 2d Sess. 5 (1952). (Footnotes omitted.) See also S. Rep. No. 1515, 81st Cong., 2d Sess. 44 (1950).

161. See, e.g., Edye v. Robertson (Head Money Cases), 112 U US. 580, 590-91, 595, and cases cited 591-93 (1884). See also Elkison v. Deliesseline, \& Fed. Cas. 493, 494-95 (No. 4366) (C.C.D.S.C. 1823).

162. See cases cited note 139 supra.

163. See Chae Chan Ping v. United States, 130 U.S. 581, 604 (1889) ; Fong Yue Ting v. United States, 149 U.S. 698, 711-12 (1893); Nishimura Ekiu v. United 'States, 142 U.S. 651,659 (1892).

164. See text at notes 70-123 supra.

165. Edwards v. California, 314 U.S. 160, 172 (1941) ; Covington \& Cincinnati Bridge Co. v. Kentucky, 154 U.S. 204, 213 (1894); Gloucester Ferry Co. v. Pennsylvania, 114 U.S. 196, 203 (1885).

In a recent report, the State Department listed foreign commerce as the exclusive basis of congressional power over immigration. Coulter, VISA WORK OF THE DEPARTment of State and the Foreign Service 28 (Dep't of 'State Pub. No. 6510, 1958). 
yond such a facile, algebraic approach to human rights. ${ }^{166}$ Furthermore, no such theory was unequivocally accepted by the Supreme Court prior to Harisiades in immigration cases.

Since regulation of immigration is based on constitutionally delegated powers-primarily the foreign commerce power in times of peace-substantive limits to congressional authority in this field necessarily exist. In defining these limits as they relate to the power to expel, an analogy to the regulation of imports may be helpful. Indeed, import cases were relied upon to uphold exercise of both the power to exclude ${ }^{167}$ and the power to eject ${ }^{168}$ against procedural due process attacks. Imports cease to be such in the constitutional sense when they are merged in the domestic economy. ${ }^{109}$ Arguably, immigrants should likewise cease to be considered "foreign products" upon being lawfully admitted as and becoming permanent residents. ${ }^{170}$ And by analogy to the power to subject imports to further regulation after admittance, the power to expel can be viewed not as an independent power, but merely as an adjunct of the power to exclude. ${ }^{171}$

Clearly, Congress may exclude those whose "habits or condition,"172 "race or habits,"173 or "history, condition, or characteristics,"174 make them undesirable permanent residents. And when such an alien is mistakenly allowed to enter, a subsequent removal is not objectionable, provided the ejection takes

166. See Boudin, supra note 117 , at $649-50$.

Compare the treatment of the power of the states over foreign corporations in the following cases: Atlantic Ref. Co. v. Virginia, 302 U.S. 22 (1937) (power to exclude is absolute); Wheeling Steel Corp. v. Glander, 337 U.S. 562 (1949) (once corporation is "domesticated," ad valorem taxes, at least, may not be discriminatory) ; Lincoln Nat'l Life Ins. Co. v. Read, 325 U.S. 673 (1945) (reasonable conditions may be imposed on foreign corporations at time of entry). One commentator has concluded that "the power to evict a corporation from doing local business is not necessarily as broad as the power to exclude. Therein seems to lie the real nub of the matter, although a reading of most of the opinions ... discloses no such conscious rationale of the cases." Harmina, State Taxation of Interstate Commerce 235 (1953).

167. Nishimura Ekiu v. United States, 142 U.S. 651,660 (1892), relied on Hilton v. Merritt, 110 U.S. 97 (1884) (summary procedures authorized in dealing with imports).

168. Zakonaite v. Wolf, 226 U.S. 272, 275 (1912), relied on United States v. Zucker, 161 U.S. 475 (1896) (due process in proceedings to penalize improper importation of goods).

169. Hooven \& Allison Co. v. Evatt, 324 U.S. 652 (1945).

170. Immigrants are defined as ones "who seek to enter the United States for permanent residence." H.R. Rep. No. 1365, 82d Cong., 2d Sess. 37 (1952). To the same effect, see S. REP. No. 1515, 81st 'Cong., 2d ISess. 414 (1950). IApart from statutory definitions, the word "immigrant" implies one who is seeking permanent residence. See Karnuth v. United States ex rel. Albro, 279 U.S. 231, 242 (1929).

171. See Fong Yue Ting v. United States, 149 U.S. 698, 713-14 (1893); cf. Rabang v. Boyd, 353 U.S. 427,432 (1957).

172. ISee The Japanese Immigrant Case, 189 U.S. 86, 97 (1903).

173. See Wong Wing v. United States, 163 U.S. 228, 237 (1896).

174. See Lapina v. Williams, 232 U.S. 78, 91 (1914). 
place within a reasonable time after entry, before a substantial change of position, in human terms, has occurred. ${ }^{175}$

Unlike those of imports, the undesirable characteristics of human beings, with the questionable exception of race, are not easily identifiable. Proof of initial excludability, therefore, is not an easy matter. As a consequence, it is reasonable to prescribe that certain postentry conduct be taken as disclosing excludable qualities or characteristics. That is, the alien's subsequent "character and conduct ... [may] determine the question of exclusion or removal."178 So viewed, expellable acts are merely substitutes for proof of initial excludability, and the power to eject is merely the power to effectuate a delayed exclusion. ${ }^{177}$

Thus, the alien's right to remain may be made to depend upon the performance of certain conditions imposed at the time of entry. ${ }^{178}$ But these conditions must reasonably relate to regulation of immigration of aliens, and not to the furtherance of other policies not connected with the fact of their alienage. Absent such a relationship, expulsion can no longer be justified as a valid regulatory measure. The implications of this view will be developed later, but for proper orientation extensive consideration of the cases between Fong $Y u e$ Ting and Harisiades is first necessary.

\section{The Keller Case and Substantive Due Process}

Keller v. United States ${ }^{179}$ is the second, and to date the last, case in which the Court has held legislation ostensibly aimed at regulating immigration unconstitutional. ${ }^{180}$ Keller considered the validity of section 3 of the Act of Feb. 20,1907 , which prescribed criminal liability for harboring alien prostitutes within three years of their entry. ${ }^{181}$ The defendants were citizens, who had

175. The bare fact of residence, however acquired, entitles an alien to procedural due process. See Shaughnessy v. United States ex rel. Mezei, 345 UıS. 206, 212 (1953) (dictum).

176. See Keller v. United States, 213 U.S. 138, 148 (1909).

177. For the distinction between postentry ejection statutes and ordinary statutes of limitation upon the right of removal after an illegal or erroneous entry, see text at notes 230-54 infra.

It has been recommended that no expulsions be based on the postentry conduct of aliens admitted for permanent residence. See Corsi, PATHS to THE NEW WORLd: AxIERIcan Immigration-Yesterday, TOday and Tomorrow 40 (1953); Maslow, Recasting Our Deportation Law: Proposals for Reform, 56 Colum. L. Rev. 309, 324 (1956). As a policy proposal this has much to recommend it, but it is not a proper view of the legitimate exercise of constitutional power. Cf. Brolan v. United States, 236 U1S. 216, 219-20 (1915) (discussed note 186 infra).

178. See Zakonaite v. Wolf, 226 U.S. 272 (1912) ; Pearson v. Williams, 202 U.S. 281,284 (1906).

179. 213 U.S. 138 (1909).

180. The other was Wong Wing v. United States, 163 USS. 228 (1896), which involved the validity of imposing criminal sanctions without observing procedural safeguards.

181. Ch. $1134, \S 3,34$ Stat. 899 . 
purchased a brothel in which an alien woman of less than three years' residence was an inmate. The evidence showed that defendants had not procured her entry, and that they were unaware of when she had entered. ${ }^{182}$ Counsel for the defense argued that applying the prescribed criminal penalties to defendants would violate the reserved police power of the states. ${ }^{183}$ The Government, on the other hand, sought to justify the act under the conceded congressional power to regulate immigration. ${ }^{184}$

Thus the issue before the Court was whether the provision in question was sufficiently related to any power of the federal government to justify the invasion of an area of state authority. Mr. Justice Brewer, writing for the majority, first determined that the statute could not be justified under the treaty power, ${ }^{185}$ then turned to the foreign commerce power as a possible basis. On the facts of the case, he concluded that there was no reasonable relation between the regulation of immigration and the conduct of the defendants which the statute made criminal, ${ }^{186}$ and therefore, that this attempted application of the power over immigration was unconstitutional. ${ }^{187}$

In reaching this result, the majority expressly left open the question of the extent of congressional power over resident aliens, ${ }^{188}$ in significant contrast to the modern position that consideration of this question is foreclosed by Fong Yue Ting.

Mr. Justice Holmes, dissenting, felt that the legislation was a reasonable exercise of the power over immigration. To support his position, he undertook to define the limits of the power over resident aliens. ${ }^{180}$ While he dis-

182. 213 U.S. at 147.

183. Id. at 140-41 (argument for plaintiff in error).

184. Id. at 141-43 (argument for defendant in error).

185. Id. at 147 .

186. Id. at 147-48.

The meaning of Keller was placed beyond doubt in Brolan v. United States, 236 U.S. 216 (1915), a case involving the power of Congress to punish a conspiracy to import opium, and a conspiracy to receive, conceal, and facilitate the transportation of opium illegally imported. In holding the contention of lack of power frivolous, the Court distinguished Keller, stating that there "the act punished not the harboring of persons for immoral purposes who had been brought into the United States in violation of the prohibition against importation, but its provision also embraced the harboring of persons for immoral purposes if they were aliens, even although $[s i c]$ they had come into the United States lawfully." Id. at 221-22.

187. 213 U.S. at 147-49. Compare United IStates v. Evans, 333 U.S. 483 , 488-89 (1948).

188. 213 U.S. at 144.

189. 213 U.S. at 149. Holmes relied on Lees v. United States, 150 U.S. 476 (1893). Decided shortly after Fong Yue Ting, Lees upheld the penalty provisions of the Act of Feb. 26, 1885, ch. 164, $\$ 3,23$ Stat. 333, which provided for a forfeiture for every alien brought into the country in violation of the Act, the Court stating:

[S] ince the Chinese Exchusion Case [Chae Chan Ping] . . . and the case of Fong Yue Ting v. United Siates ... affirming fully the power of Congress over the exclusion of aliens, there can be little doubt in the matter. Given in Congress 
sented from the holding that the legislation was unconstitutional as applied, the views he expressed concerning the extent of the substantive power over the resident alien may be taken to be those of the entire Court. ${ }^{100}$ Holmes' ideas rest on the accepted meaning and purport of the conditional entry theory of expulsion. Since his brief opinion in Bugajewitz v. Adams, ${ }^{101}$ decided four years after $K e l l e r$, is generally held to place any question of possible substantive limits to the power to expel beyond debate, ${ }^{192}$ the views set forth in Keller must be quoted almost in their entirety to provide an understanding of Holmes' true position.

For the purpose of excluding those who unlawfully enter this country Congress has power to retain control over aliens long enough to make sure of the facts . . . . To this end it may make their admission conditional for three years . . . . If the ground of exclusion is their calling, practice of it within a short time after arrival is, or may be, made evidence of what it was when they came in. Such retrospective presumptions are not always contrary to experience or unknown to the law .... If a woman were found living in a house of prostitution within a week of her arrival, no one, I suppose, would doubt that it tended to show that she was in the business when she arrived. But how far back such an inference shall reach is a question of degree like most of the questions of life. And, while a period of three years seems to be long, I am not prepared to say, against the judgment of Congress, that it is too long.

[I]t is fair to observe that the presumption ... is not open to rebuttal. I should be prepared to accept even that, however, in view of the difficulty of proof in such cases. Statutes of which the justification must be the same are familiar in the States .... It is true that ... [ordinarily] in such instances the legislature has power to change the substantive law of crimes, and it has been thought that when it is said to create a conclusive presumption as to a really disputable fact, the proper mode of stating what it does .... is to say that it has changed the substantive law .... . This may be admitted without denying that considerations of evidence are what lead to the change. And if it should be thought more philosophical to express this law in substantive terms, I think that Congress may require, as a condition of the right to remain, good behaviour for a certain time, in matters deemed by it important to the public wel-

the absolute power to exclude aliens, it may exclude some and admit others, and the reasons for its discrimination are not open to challenge in the courts. Given the power to exclude, it has a right to make that exclusion effective by punishing those who assist in introducing, or attempting to introduce, aliens in violation of its prohibition.

150 U.S. at 480.

190. [Holmes' dissent in Keller] was not a dissent from anything that the majority of the court had said in the case. On the contrary, it was the statement of the law as it had been declared by the court in previous cases with respect to the conditions upon which aliens are permitted to be and remain in this country, and upon that subject unquestionably expressed the views of the whole court.

Looe Shee v. North, 170 Fed. 566, 571 (9th Cir. 1909).

191. 228 U.S. 585 (1913).

192. See text at notes $276-94$ infra. 
fare and of a kind that indicates a preexisting habit that would have excluded the party if it had been known .... 193 $^{103}$

From this formulation of the theory of the power to expel, it becomes quite clear why "the classes of aliens who are subject to deportation are not wholly made up of those who enter in violation of the law; in some cases causes for deportation may arise after lawful entry."194

The fact that an alien may enter lawfully, and yet remain unlawfully, does not mean that there is unlimited power to expel. Obviously, one who is admitted for temporary purposes may overstay his lawful period of residence and be ejected. Likewise, one whose conduct subsequent to a lawful entry falls short of prescribed standards may be ejected. But to sanction such action is not to concede unlimited power to banish. As Holmes' opinion indicates, deportation for postentry acts is based on a conclusive presumption that the alien was excludable at entry. Only by applying such a rationale can the deportation of resident aliens be justified as a regulation of immigration. ${ }^{105}$ It would seem that when the alien is able to show that the presumption is invalid as applied to him, expulsion can no longer be thought of as a regulation of immigration and must be considered a punishment for the proscribed act.100

Although drawing conclusions from dicta is frequently risky, it seems reasonable to say that Holmes did not consider the power to expel the mirror image of the power to exclude. If this had been his view, the entire examination of the theory of the statute as applied to aliens would have been unnecessary. His opinion is not a hasty, ill-considered dissent; on the contrary, it is the most lucid expression of the Court's understanding of the conditional entry theory of expulsion. To make Holmes the villain responsible for the present view concerning the power of Congress over the resident alien, therefore, misses the point of both opinions in Keller. ${ }^{197}$ Although Holmes' decision in

193. 213 U.S. at 149-50. Holmes' opinion was concurred in by Harlan and Moody, JJ.

On the validity of conclusive presumptions, compare Bailey v. Alabama, 211 U.S. 452 (1908), the only federal case cited by Holmes which has not already been discussed. It involved an Alabama statute making it a crime to receive salary in advance under written contract with the intent to defraud the prospective employer. The statute provided that the failure to perform the services was prima facie evidence of the prohibited fraudulent intent. The presumption was attacked as violating the thirteenth amendment, as a device to reduce Negroes to a status of semiservitude. Holmes refused to pass on the question of the validity of the presumption on the ground that at the trial the state might prove its case independent of the statutory presumption. He noted, however, that: "It may be, although presumptions of intent from somewhat remote subsequent conduct are not unknown to the common law ... that the amendment creates a presumption that cannot be upheld." Id. at 454 . The presumption was ultimately held invalid. Bailey v. Alabama, 219 U.S. 219 (1911).

194. Lewis v. Frick, 233 U.S. 291, 303 (1914).

195. Compare Trop v. Dulles, 356 U.S. $86,97-98$ (1958) (dictum).

196. Compare the discussion of deportation under the war power, note 57 supra.

197. See Comment, 20 U. 'CHr. L. Rev. 547, 550-51 (1953) (Holmes' dissent based on view that power over aliens is absolute). The significance of the interpretation of the conditional entry theory advanced here was also missed by Bullitt, who characterized it 
Bugajezitz is currently accepted as upholding the power to banish, his dissent in Keller shows that Bugajewitz is being interpreted incorrectly. Furthermore, the Keller dissent contains the germ of a substantive due process theory that would strike down claims to unlimited power to banish long-term resident aliens.

\section{Sources of Power-A Summary}

From the first consideration of the question, the power to regulate immigration has been held to be part of the delegated powers of the federal government. Nevertheless, inherent sovereignty has come to be considered as a second basis of power. The doctrine of inherent sovereignty as applied to immigration originated as an answer to the assertion that the Government could not, under international law, deprive Chinese laborers of their treaty rights to return to or remain in the United States, but it is now invoked in nearly all cases involving alien regulation. Given that the necessary sovereign powers have been delegated to the federal government, however, it would seem fairly clear that to urge a dual basis for governmental action, when a single expressly delegated power is sufficient to support it, is not only misleading but redundant. Unfortunately, the Court tends to talk of sovereignty whenever presented with a flesh-and-blood exclusion or expulsion, relying solely on the foreign commerce power only when congressional power over immigration is less dramatically exercised.198 And although in theory, even sovereign powers are not constitutionally unlimited, ${ }^{190}$ uncritical espousal of the inherent sovereignty doctrine has submerged the question of possible substantive limits.

\section{Ejection of the Resident Alien}

Legal doctrines are not self-generated abstract categories. They do not fall from the sky; nor are they pulled out of it. They have a specific juridical origin and etiology. They derive meaning and content from the circumstances that gave rise to them and from the purposes they were designed to serve. To these they are bound as is a live tree to its roots. . . . They cannot be wenched from it and mechanically transplanted into an alien, unrelated conte.rt without suffering mutilation or distortion.

Mr. Justice Frankfurter ${ }^{200}$

as a theory of an "implied contract between the immigrant and the natives whose ancestors preceded him to this country ... [which] smacks of indentured servitude ...." Bullitt, Deportation as a Dcuial of Substantive Due Process, 28 WAsh. L. Rev. 205, 217 n.62 (1953).

198. Compare Harisiades v. Shaughnessy, 342 U.S. 580 (1952), with Edye v. Robertson (Head Money Cases), 112 U.S. 580, 591 (1884).

199. See United States v. Wong Kim Ark, 169 U.S. 649 (1898). Although the court stated that "it is the inherent right of every independent nation to determine for itself, and according to its own Constitution and laws, what classes of persons shall be entitled to its citizenship," id. at 668 , it rejected an asserted exercise of this inherent right by the executive branch of the Government, when the exercise was inconsistent with the constitutional limits of the power arising from the constitutional definition of citizenship.

200. Reid v. Covert, 354 U.S. 1, 50 (1957) (concurring opinion). 


\section{Introduction}

From the preceding analysis, it can be seen that Harisiades was not fully supported by earlier cases. Admittedly, it is easy to misapprehend the sweeping language of Fong Yue Ting when it is divorced from the legislation and constitutional contentions involved. The subsequent disregard of Keller may be explained by the facts that the defendants in that case were citizens and the substantive limitations on federal action invoked stemmed from the powers constitutionally reserved to the states. Thus Keller was not the sort of precedent likely to be cited by counsel in cases involving the rights of resident aliens, although its insistence upon a rational nexus between regulations promulgated under the immigration powers and immigration itself is applicable to such cases. Perhaps a more important reason why the Keller opinions have been ignored, however, is the opinion of Mr. Justice Holmes four years later in Bugajewitz, which is commonly construed as settling the constitutional status of all resident aliens. A proper understanding of Bugajewitz is impossible without first considering the various types of resident aliens and the purpose and intent of the legislation involved in the case.

\section{Types of Resident Aliens}

Four types of resident aliens should be distinguished: the temporary, the illegal, the erroneously admitted, and the properly admitted permanent resident. The temporary resident is clearly not entitled to remain permanently, unless he achieves an adjustment of status. ${ }^{201}$ The illegal entrant is in the same constitutional position as the alien seeking admittance. ${ }^{202}$ At least where he is apprehended shortly after entrance, his deportation may be considered an exclusion. ${ }^{203}$

The erroneously admitted alien, on the other hand, presents different problems. If allowed to enter after following all prescribed procedures, he cannot be considered to be illegally within the country unless entry was obtained by fraud. Nevertheless, when his characteristics are such as to have made him excludable had the facts been known, subsequent ejection is proper as a legitimate means of effectuating exclusion.

But the properly admitted permanent resident, who achieves admittance neither erroneously nor by fraud, must be sharply distinguished from aliens in the other categories. This distinction is sometimes difficult since the erroneous nature of entry is now generally determined from postentry conduct. It is possible, therefore, to confuse the last two types of residents described unless the need for a causal connection between the proscribed postentry conduct

201. See Immigration and Nationality Act of 1952, § 101 (a) (15), 66 Stat. 167, \& U.S.C. $\$ 1101(a)(15)(1952)$.

202. See, e.g., United States ex rel. Turner v. Williams, 194 U.S. 279, 289-90 (1904).

203. For statutes referring to ejection of aliens as "removal," see Act of May 6, 1882, ch. 126, $\S 12,22$. Stat. 61 ; Act of July 5, 1884, ch. 220, 12,23 Stat. 117; Act of Sept. 13, 1888, ch. 1015, § 13, 25 Stat. 479; Act of May 3, 1892, ch. 60, § 2, 27 Stat. 25. 
and preentry characteristics is kept clearly in mind. For example, practicing prostitution within a week of entry, to adopt Holmes' illustration, is a postentry act clearly supporting a presumption of initial excludability. When a young woman becomes a prostitute twenty years after her entry as an infant such a presumption becomes irrational. In the latter case, the woman is a properly admitted permanent resident; her antisocial or undesirable conduct is the exclusive product of our society and has nothing to do with her foreign birth.

Using the foregoing distinctions it can be shown that the cases which are currently accepted as upholding the power to banish long-term lawful residents were concerned with the entirely different problems raised by other types of resident aliens.

\section{Types of Expulsion Statutes}

As an aid to understanding the legislation dealing with the four classes of resident aliens, the corresponding types of expulsion statutes should be noted. A Senate report has classified them as follows:

1. Violation of status or terms of conditional entry. This includes all of the non-immigrant categories as well as the student who is designated as a non-quota immigrant....

2. Entering without inspection or by fraud.

3. Causes existing at time of entry. This includes aliens excluded by emergency or wartime restrictions, aliens with fraudulent or no documents, aliens convicted or admitting the commission, prior to entry, of a crime involving moral turpitude, immoral aliens, anarchistic or other subversive aliens, and aliens with mental, physical, economic, or educational disqualifications.

4. Causes arising after entry. This includes alien smugglers of aliens, aliens convicted of crime, immoral aliens, anarchistic or other subversive aliens, and aliens becoming public charges. ${ }^{204}$

Type I involves temporary residents, or aliens admitted pursuant to treaty status. Type II covers illegal residents. Type III involves erroneously admitted residents. Type IV, on the other hand, may apply to either erroneously admitted or properly admitted residents. Thus, serious substantive due process questions arise only in connection with Type IV legislation.

\section{Development of the Conditional Entry Theory}

Viewing immigration legislation retrospectively, a growing recognition of the distinction between illegal entrants and erroneously admitted residents can be discerned. Prior to 1903, however, most legislation dealt with "unlawful" residents, a phrase which could, textually at least, be construed to apply to both types. This legislation included both the general immigration laws and the Chinese Exclusion Acts, both of which will now be analyzed.

204. S. REp. No. 1515, S1st Cong., 2d Sess. 71 (1950). 


\section{The Chinese Exclusion Acts}

The Act of May 6, 1882, began the exclusion of Chinese laborers, providing :

That from and after the expiration of ninety days after the passage of this act ... the coming of Chinese laborers to the United States be, and ... is hereby, suspended; and during such suspension it shall not be lawful for any Chinese laborer to come, or, having so come after the expiration of said ninety days, to remain within the United States. ${ }^{205}$

It also prohibited the landing of any persons "in violation of law,"200 and further provided "that ... any Chinese person found unlawfully within the United States shall be . . . removed . . . after being . . . [so] found."207

These provisions were carried forward in the Acts of July 5, 1884, ${ }^{208}$ and Sept. $13,1888 .{ }^{209}$ Less than a month later, the Act of Oct. 1, 1888, prohibited Chinese laborers who had formerly been lawful residents "to return to, or remain in, the United States."210

Read abstractly, the repeated references to those not entitled to "remain" within the United States might be construed as referring to postentry causes for expulsion. But it is clear from the relation of the expulsion clauses to the exclusion provisions that only those who entered or reentered illegally could be ejected.

In spite of the provision for the ejection of illegally resident Chinese, the exclusion program did not prove effective. The Act of May 5, 1892, ${ }^{211}$ therefore, approached the problem in a new way. It continued the earlier ejection provisions but, since it had proved difficult to determine who were and who were not entitled to be or remain in the United States, section 6 established what amounted to a conclusive presumption of unlawful entry for failure to obtain a certificate of residence. ${ }^{212}$ Congress thus shifted the burden of proof of lawful entry to the Chinese laborer. This was first upheld in Fong Yue

205. Ch. $126, \S 1,22$ Stat. 59. The Act of Feb. 19, 1862, ch. 27,12 Stat. 340 , was enacted to prohibit involuntary transportation of Chinese "coolie" laborers into the United States. The act did not apply to voluntary immigrants.

206. Ch. 126, $\S 9,22$ Stat. 60.

207. Ch. 126, \& 12, 22 Stat. 61.

208. Ch. 220, § 12, 23 Stat. 115.

209. Ch. 1015, \& 13, 25 Stat. 479. This act impliedly recognized a distinction between laborers intending to remain and others; it provided that "no Chinese laborer ... shall be permitted to return to the United States unless he has a lawful wife, child, or parent in the United States, or property therein of the value of one thousand dollars, or debts of like amount due him and pending settlement. .." Ch. 1015, § 6, 25 Stat. 477.

210. Ch. 1064, 25 Stat. 504, upheld in Chae Chan Ping v. United States (Chinese Exclusion Case), 130 U.S. 581 (1889). See also Wan Shing v. United States, 140 U.S. 424,426 (1891) (method of proof of right to reenter by one claiming to be a merchant).

21.1. Ch. 60, 27 Stat. 25.

212. Ch. $60, \S 6,27$ Stat. 25 . 
Ting $v$. United States. ${ }^{213}$ Later, on slightly different facts, it was again upheld in Li Sing v. United States. ${ }^{214}$

\section{The General Immigration Acts}

Except for the Alien Act of 1798, 15 the first general statute to regulate immigration was the Act of March $3,1875,{ }^{216}$ which excluded convicts and

213. 149 U.S. 698 (1893). In 1893, Congress amended $\S 6$ of the 1892 act, so that the right to remain had to be established "by at least one credible witness other than Chinese," Act of Nov. 3, 1893, ch. 14, 28 Stat. 7, rather than "one credible white witness."

214. 180 U.S. 486 (1901). Occasionally relied on to support broad powers to expel, see, e.g., Fok Yung Yo v. United States, 185 U.S. 296, 302 (1902), Li Sing involved a resident alien who returned to China and subsequently obtained reentry into the United States with a certificate purporting to establish that he was a merchant before leaving this country. Confronted by evidence that he was a laborer, and had been one for a number of years prior to his departure, he failed to prove by non-Chinese witnesses that this was not in fact true. His certificate was not conclusive under the terms of the Act of July 5, 1884, ch. 20, 23 Stat. 115-16. His counsel's argument that placing the burden of proof of lawful reentry on a resident was improper was rejected on the authority of Fong Yue Ting. 180 U.S. at 493. Since, on its facts, $L i$ Sing involved a Type II or III ejection, the broad statement that "[T]he United States can forbid aliens from coming within their borders, and can expel them from the country. . ..", id. at 495, can be taken to mean merely that those who were excludable at entry can be ejected. $L i$ Sing is also confirmation that the significance of Fong Yue Ting was its approval of the shift in the burden of proof. The last variation of any significance with respect to exclusion and the removal of Chinese laborers was the Act of Aug. 18, 1894, ch. 301, 28 Stat. 390, which, "to prevent unlawful entry of Chinese into the United States," provided that "in every case where an alien is excluded from admission under any law or treaty now existing or hereafter made, the decision of the appropriate immigration or customs officers, if adverse to the admission of such alien, shall be final, unless reversed on appeal to the Secretary of the Treasury." The validity of this act was upheld in Lem Moon Sing v. United States, 158 U.S. 538, 549 (1895). Although the exclusion there was approved, Mrr. Justice Harlan's views on the constitutional status of the resident alien offer a significant contrast to modern theory :

His [the alien's] personal rights when he is in this country ... are as fully protected by the supreme law of the land as if he were a native or naturalized citizen of the United States. But when he has voluntarily gone from the country, and is beyond its jurisdiction, being an alien, he cannot re-enter the United States, in violation of the will of the government as expressed in enactments of the lawmaking power.

Id. at 547-48.

Another Chinese exclusion case which has become precedent for banishment, Fok Yung Yo v. United States, 185 U.S. 296 (1902), involved only the power to prohibit, by administrative regulations, the right of transit through the United States, in an effort to enforce the power to exclude and to prevent illegal entry.

All three of the cases discussed here were relied on to support broad expulsion powers in Harisiades v. Shaughnessy, 342 U.S. 580,587 n.1.1 (1952).

215. Ch. 58,1 Stat. 570.

216. Ch. 141,18 Stat. 477. 
prostitutes. ${ }^{217}$ Containing no postentry ejection clauses, the act provided only for deportation after exclusion. ${ }^{218}$ This method of enforcement was again employed in the Act of Aug. 3, 1882,219 which added idiots, lunatics, and persons likely to become public charges to the excludable classes, and in the Act of Feb. 23, 1887,220 covering contract laborers. Such provisions have been carried forward through all subsequent enactments, and are now, in varied language, part of the 1952 act. ${ }^{221}$

The Act of March 3, 1891,222 added further to the expanding excludable classes, ${ }^{223}$ but, more important, introduced ejection to the general immigration laws. Section 11 of the act provided in part "that any alien who shall come into the United States in violation of law may be returned as by law provided, at any time within one year thereafter . . ."224 Insofar as this applied to illegal entrants, it was a Type II provision. If the phrase "in violation of law" is taken to include "erroneously," however, it was also Type III. In either case, however, the last words quoted were in the nature of a statute of limitations.

The Act of March 3,1903,225 altered the provisions respecting postentry removal. Section 21 stated that those who entered illegally could be deported within three years of entry, ${ }^{226}$ while section 20 provided for the ejection within two years of entry of aliens whose preentry characteristics made them ineligible to enter. ${ }^{227}$ In both cases the statute of limitations approach was retained.

With regard to the illegal entrant, the Act of Feb. 20, 1907,228 carried for-

217. Ch. $141, \S \S 3,5,18$ Stat. 477 . It is worth noting that these original excludable classes remain among the principal classes involved in Type IV expulsions.

218. Ch. $141, \S 5,18$ Stat. 477.

219. Ch. 376, \& 4, 22 Stat. 214.

220. Ch. 220, \& 8, 24 Stat. 415.

221. Immigration and Nationality Act of 1952, § 237(a), 66 Stat. 201, 8 U.S.C. $\S 1227$ (a) (1952).

222. Ch. 551, 26 Stat. 1084.

223. For example, paupers, persons suffering from loathsome or dangerous contagious diseases, and persons assisted by others to come. Ch. 551, $\$ 1,26$ Stat. 1084. It also added the public charge provision upheld in Nishimura Ekiu v. United States, 142 U.S. 651 (1892).

224. Ch. 551, § 11, 26 Stat. 1086.

225. Ch. 1012, 32 Stat. 1213. This act added to the excludable classes epileptics, persons insane within five years, or who had had two or more attacks of insanity, professional beggars, anarchists, persons who believed in or advocated the overthrow, by force and violence, of the government, or of all governments or forms of law, or the assassination of public officials, and procurers.

226. Ch. 1012, § 21, 32 Stat. 1218.

227. Ch. 1012, § 20, 32 Stat. 1218. See the interpretation of this clause in S. REP. No. 1515, 81st Cong., 2d Sess. 53 (1950).

228. Ch. 1.134, 34 Stat. 898. This act added to the excludable classes imbeciles, feebleminded persons, persons with physical or mental defects which may affect their ability to earn a living, persons afficted with tuberculosis, children unaccompanied by their 
ward the relevant provisions of the 1903 act with slight modifications, retaining the three-year limitation.220 But the 1907 act's treatment of the erroneously admitted alien marked a new departure which can best be appreciated by focusing on legislation dealing with that particular class.

\section{The Erroneously Admitted Alien}

The provisions thus far examined either prescribed ejection of unlawful Chinese residents at any time, or ejection of general immigrants within a limited period of time. Statutes containing limitation periods dealing particularly with erroneously admitted residents were also adopted as part of the general immigration laws. Thus, the Act of Oct. $19,1888,{ }^{230}$ dealing with contract laborers who had been allowed to enter, amended the 1885 and 1887 acts :

To authorize the Secretary of the Treasury, in case he shall be satisfied that an immigrant has been allowed to land contrary to the prohibition of that law, to cause such immigrant within the period of one year after landing or entry, to be taken into custody and returned to the country from whence he came.... ${ }^{231}$

This Type III provision is the first clear legislative recognition of the erroneously admitted alien. Similar clauses of widening applicability were included in subsequent acts. ${ }^{232}$ The 1907 act provided for deportation of erroneously admitted aliens within three years of their entry. ${ }^{233}$

Of greater significance to the modern law of expulsion was the development of presumptions of erroneous admittance, which made postentry acts proof of the preentry character or conditions upon which removal was predicated. This type of provision has evolved into the modern "expellable acts."

The first statute to make postentry conduct grounds for removal did not adopt the presumption approach. Section 11 of the Act of March 3, 1891, provided in part "that ... any alien who becomes a public charge within one year after his arrival ... from causes existing prior to his landing therein shall be deemed to have come in violation of law and shall be returned as aforesaid."234 The requirement of a causal relationship between the preentry

parents, persons who admit commission of a crime involving moral turpitude, and women coming for immoral purposes. Ch. 1134, \$ 2, 34 Stat. 898.

229. The protection given the resident alien by the "statute of limitations" theory was somewhat curtailed by later holdings that, by omitting the word "immigrant" from the 1903 to 1907 acts, Congress had expressed an intent to exclude all entering aliens "irrespective of any qualification arising out of a previous residence or domicil in this country." Lapina v. Williams, 232 U.S. 78, 86-91 (1914); accord, Lewis v. Frick, 233 U.S. 291, 296-97 (1914).

230. Ch. 1210, 25 Stat. 565.

231. Ch. 1210, 25 Stat. 566.

232. See Act of March 3, 1891, ch. 551, $\S ~ 1,10,11,26$ Stat. 1084; Act of March 3, 1903 , ch. 1012, $\$ 20,32$ Stat. 1213.

233. Act of Feb. 20, 1907, ch. 1134, § 20, 34 Stat. 904.

234. Ch. 551, § 11, 26 Stat. 1086. 
condition and the postentry conduct is quite clear. The burden of proving this causal connection was placed upon the Government. ${ }^{235}$

The Fong Yue Ting Court had, however, upheld the power of Congress to place the burden of proof of lawful entry upon the alien. In Li Sing v. United States, ${ }^{236}$ this shift of the burden had again been approved, this time with respect to conduct both prior and subsequent to entry. ${ }^{237}$ From this point, only a short step was required to make postentry conduct alone conclusive evidence of erroneous or unlawful admittance. This step was taken in the Act of Feb. 20, 1907.238

Since the exclusion act of 1875 , the importing of alien prostitutes had been a crime. ${ }^{239}$ The 1907 act made two substantial changes. The act made it a crime to keep an alien prostitute in a house of ill fame within three years of her entry $;{ }^{240}$ and it further provided:

That ... any alien woman or girl who shall be found an inmate of a house of prostitution or practicing prostitution, at any time within three years after she shall have entered the United States, shall be deemed to be unlawfully within the United States and shall be deported as provided by sections twenty and twenty-one of this Act. ${ }^{241}$

That this provision was intended merely as a substitute for proof of initial excludability is evident from the fact that alien prostitutes had been excluded since $1875,{ }^{242}$ while those who entered either illegally or erroneously were deportable within three years under other sections of the 1907 act. ${ }^{243}$

In addition to the provision just discussed, the 1907 act established a Joint Congressional Commission on Immigration to make a "full inquiry, exami-

235. The burden was removed by the Act of Feb. 5,1917 , ch. $29, \S 19,39$ Stat. $\$ 90$. Congressional intent is clear from the following:

The existing law authorizes the deportation of any alien who becomes a public charge, within the specified time limit, from causes existing prior to entry. . . . [This is to be changed so that it reads] "[F]rom causes not affirmatively shown to have arisen subsequent to landing." . . Many cases arise in which it is practically impossible for the Government to carry the burden imposed upon it as the existing law is worded....

S. REP. No. 352, 64th Cong., 1st Sess. 14 (1916).

Immigration and Nationality Act of 1952, $\$ 241$ (a) (8), 66 Stat. 205, \& U.S.C. $\S 1251$ (a) (8) (1952), provides for the expulsion of any alien who, "in the opinion of the Attorney General, has within five years after entry become a public charge from causes not affirmatively shown to have arisen after entry."

236. 180 U.S. 486 (1901).

237. See note 214 supra.

238. Ch. 1134, § 3, 34 Stat. 900.

239. Act of March 3,1875, ch. 141, § 3, 18 Stat. 477.

240. Ch. 1134, § 3, 34 Stat. 899. This part of $\$ 3$ was held unconstitutional in Keller v. United States, 213 U.S. 138 (1.909).

241. Ch. 1134, § 3, 34 Stat. 899-900.

242. See text at notes $215-21$ supra.

243. Ch. 1134, $\$ \$ 20,21,34$ Stat. 904-05. 
nation and investigation."244 One of the principal objects of investigation was prostitution, which the Commission's report characterized as "the most pitiful and the most revolting phase of the immigration question."245 Concerning Keller, which had held unconstitutional the 1907 act's attempt to make "harboring" an alien prostitute a crime, the Commission observed:

The number of deportations is much smaller than that of arrests, because the effectiveness of the law ... has been very greatly lessened by the decision .... Naturally it is much more difficult to weave a chain of evidence about an importer or procurer than to convict a person of "harboring." 246

It noted further that "it is often extremely difficult to prove the illegal entrance of either women or procurers," 247 and that the woman "is invariably warned of the danger of deportation and instructed what lies [about the time of entry] to tell if she is arrested in order to avoid deportation."248

The Commission's recommendations ${ }^{249}$ led to the 1910 amendments to the 1907 act. $^{250}$ These added to the excludable classes persons who are supported by or receive proceeds of prostitution, ${ }^{251}$ overcame the specific constitutional objections raised in $\mathrm{Keller},{ }^{252}$ and, in view of the then existing inability to

244. Ch. 1134, \$ 39, 34 Stat. 909.

245. S. Doc. No. 747, 61st Cong., 3d Sess., vol. 2, at 327 (1910). This is the abstract of the Commission's findings and conclusions and is the most concise and well organized version of its views. The same material is also found in its preliminary (S. Doc. No. 196, 61st Cong., 2d Sess. (1909)) and final (S. Doc. No. 753, 61st Cong., 3d Sess. 53-124 (1910)) reports on the white slave question.

246. S. Doc. No. 747 , supra note 245 , vol. 2 , at 331 .

247. Id. vol. 2 , at 339 .

248. Id. vol. 2, at 341. The Commission conducted a study between November 15, 1908 , and March 15, 1909, of "alien women convicted in the night court of the city of New York of soliciting on the streets and of being inmates of disorderly houses," $i d$. vol. 2 , at 332, in an attempt to ascertain the dates of their entry into the United States. The study showed that less than 5\% of the 581 women questioned admitted arriving within three years. From this, the Commission deduced that widespread knowledge of the expulsion law had led to continual evasion. Id. vol. 2, at 333.

249. These included:

1. That section 3 of the immigration act of February 20, 1907, be amended by removing the limitation of three years after the date of landing within which the prostitute or procurer must be found.

Comment.-The evils of the traffic are ordinarily not lessened with the length of time the criminal or prostitute remains in the country.

....

4. The burden of proof regarding the date and place of landing should be placed upon the alien, if those facts are needed.

S. Doc. No. 196, 61st Cong., 2d Sess. 35 (1909).

250. Act of March 26, 1910, ch. 128, 36 Stat. 263; see S. Doc. No. 747, supra note 245 , vol. 2 , at $327,577$.

251. Ch. $128, \S 1,36$ Stat. 263.

252. The relevant portion of the section of the 1907 act was amended to read: "[W]hoever shall keep, maintain, control, support, employ, or harbor in any house or 
prove time of entry, ${ }^{253}$ as well as the apparent conspiracy of the underworld to avoid expulsion by lying about the critical date, eliminated the three-year limitation period within which the conclusive presumption of initial excludability had formerly operated..$^{254}$

Prior to the 1917 act, then, the only ejection provisions which had no limitation period were those dealing with erroneously admitted procurers and prostitutes, who frustrated proof of the time of their entry, and those dealing with Chinese laborers, who were presumed to be nonassimilable, and who, in any event, had been allowed to enter or remain as foreign nationals pursuant to treaties with China, and not as potential citizens.

\section{The Significance of Bugajervitz}

Pre-Bugajerritz cases. The constitutionality of the provisions of the 1907 act dealing with prostitutes was swiftly established. In Low Wah Suey $v$. Backus, ${ }^{255}$ the first case under these provisions presenting a constitutional issue, the prostitute involved was the wife of a citizen. Counsel for the husband, who was the petitioner in the case, argued that the woman's marriage to a citizen placed her outside the intent of the act, and that she had been denied procedural due process. ${ }^{256}$ Thus, the question of substantive limits to the power to expel was not before the Court.

After considering in detail the procedural objections raised, the Court concluded that since petitioner's wife, being a Chinese, was not entitled to become a citizen even though married to one, she could be ejected under the statute. As the Court interpreted the act:

other place, for the purpose of prostitution or for any other immoral purpose, in pursuantce of such illegal importation, any alien ...." Ch. 128, \$2, 36 Stat. 264. (Emphasis added.)

Section 3 of the 1907 act, as amended by $\S 2$ of the 1910 act, provided that aliens convicted of the crimes enumerated in $\$ 3$ were to be deported after serving their sentences. Ch. $128, \S 2,36$ Stat. 265. Although this provision appears to be somewhat similar to the modern concept of deportable acts, the act can be interpreted merely as raising a conclusive presumption of initial excludability based on the evidence provided by the conviction. Admittedly, the legislative history, although far from conclusive, gives some indication that Congress intended to deport alien procurers regardless of time of entry. See H.R. REp. No. 44, 61st Cong., 2d Sess. 1. (1909) ; S. Doc. No. 196, supra note 249, at 36. But under the theory existing at that time of the extent of power over aliens, such an intent might well have been unconstitutional. See Keller v. United States, 213 U.S. 138,149 (1909) (dissenting opinion). Thus the suggested interpretation of the statute might have been adopted to save its constitutionality had it been tested. Compare Hawker v. New York, 170 U.S. 189, 196 (1898).

253. Only since the Act of June 29,1906 , ch. $3592, \S 1,34$ Stat. 596, which established the Bureau of Immigration and Naturalization, have immigration stations kept records of entries. Under present regulations, aliens who establish entry prior to June 30, 1906, are presumed to have been admitted lawfully. 8 C.F.R. $\$ 4.2(a)$ (1958).

254. Ch. 128, $\$ 2,36$ Stat. 265.

255. 225 U.S. 460 (1912). The 1910 amendments were already in force. The woman had been arrested within three years of entry, however, and the Government and the Court both assumed that the three-year limitation period of the 1907 act still applied.

256. 225 U.S. at 469-74. 
It was the manifest purpose of Congress . . . to prevent the introduction and keeping in the United States of women of the prohibited class. The object of the act was to exclude alien prostitutes, or, if they entered and were found violating the statute within the period prescribed, to return them to the country whence they came. ${ }^{257}$

This interpretation of the statute is clearly consistent with the position taken in the Keller dissent. Thus, while Low Wah Suey recognized that one may be deprived of the right to remain solely because of acts subsequent to entry, it must be remembered that the statute involved raised a conclusive presumption of erroneous entry from those acts.

In Zakonaite v. Wolf, ${ }^{258}$ which was decided shortly after Low Wah Suey, counsel for Zakonaite contended that she had been denied procedural due process, and, in an effort to come within the rule of Keller, argued in substance that:

The provisions of the immigration act in question, vesting in the Federal authorities the power to try an immigrant, lawfully admitted into the United States, for violation of the penal laws of the state of which he has become a resident, constitute an interference with the police powers, which are matters reserved for regulation by the states, and not within any powers delegated to Congress by the Constitution.259

Although this argument was dismissed without discussion, ${ }^{260}$ the Court's action should not be interpreted as an acceptance of the theory that there are no substantive limits on the power to expel. In disposing of the procedural due process issue, the Court made clear that it regarded the case not as a criminal prosecution, but as a proceeding to enforce a regulation imposed on immigration. ${ }^{201}$ Since Zakonaite was unquestionably a prostitute at the time of the proceedings and introduced no evidence that she had not been one at time of entry, the regulation as applied to her was reasonably related to the permissible congressional policy of excluding alien prostitutes. And, since the regulation here was reasonably related to congressional power, it was irrelevant that the proscribed conduct might also involve the police power of the states. ${ }^{202}$ Thus, the Court's summary dismissal of the argument based on Keller was completely justified, and Zakonaite cannot be read as extending congressional power over resident aliens beyond the limits conceded in Holmes' earlier dissent.

A third case, Tiaco v. Forbes, ${ }^{263}$ decided one week before Bugajervitz, has occasionally been cited for the proposition that the expulsion power is con-

257. 225 U.S. at $475-76$.

258. 226 U.S. 272 (1912).

259. Brief for Appellant, 57 L. Ed. 219.

260. 226 U.S. at 275.

261. Ibid.

262. Compare Bugajewitz v. Adams, 228 U.S. 585, 591 (1913).

263. 228 U.S. 549 (1913). 
stitutionally unlimited. ${ }^{264}$ The issue in Tiaco was whether the Governor General of the Philippines could be held liable for damages to Chinese aliens whom he had deported, following a request from the Chinese government, as dangerous to public tranquility. Counsel for the plaintiffs, conceding the question of the extent of congressional power to expel aliens, argued that this power had not been delegated to the Philippine government. ${ }^{265}$ It is clear, then, that no question of substantive limits to the power to expel was before the Court.

It is interesting to note that Mr. Felix Frankfurter, in his brief for the Philippines, argued that "the expulsion of dangerous persons where the cause of danger arose subsequent to entry into the country has never been a subject of Federal regulation."266

From this, he concluded that the states were free to exclude or expel, an assertion which would be highly debatable today. ${ }^{207}$ The vital point, however, is that only two days after Bugajezritz was submitted, Frankfurter stressed that no federal legislation had as yet prescribed ejection for postentry characteristics or conditions. If he was right, then Bugajewitz could not possibly have settled the question of the existence of the power to banish for postentry acts, since the statutes before the Court in that case did not assert such a power.

To return to Tiaco, Holmes' language was very broad: "It is admitted that sovereign states have inherent power to deport aliens, and seemingly that Congress is not deprived of this power by the Constitution of the United States."268 But his citations of Fong Yue Ting, Wong Wing, Turncr, and Fok Yung Yo v. United States, ${ }^{269}$ none of which upheld unlimited power to expel, show that he intended to break no new ground but merely to affirm constitutional recognition of the power, whatever its limits. On the main point contested by plaintiffs, he concluded that:

As Congress is not prevented by the Constitution, the Philippine Government cannot be prevented by the Philippine Bill of Rights alone . . . . Deporting the plaintiffs was not depriving them of due process of law, unless on other grounds the local government was acting beyond its power. ${ }^{270}$

264. See Ex parte Bridges, 49 F. Supp. 292, 300 (N.D. Cal. 1943).

265. 228 U.S. at 552.

266. Brief for Defendants in Error, 57 L. Ed. 963.

267. See Note, Wetbacks: Can the States Act to Curb Illegal Eutry?, 6 Stax. L. REv. 287 (1954).

The authorities cited to support Mr. Frankfurter's conclusion dealt with health and quarantine laws. Compagnie Francaise de Navigation a Vapeur v. Board of Health, 186 U.S. 380, 391 (1902) ; Louisiana v. Texas, 176 U.S. 1 (1900) ; Morgan v. Louisiana, 118 U.S. 455 (1886) ; New York v. Miln, 36 U.S. (11 Pet.) 102 (1837).

268. 228 U.S. at 556-57.

269. 185 U.S. 296 (1902).

270. 228 U.S. at 557. 
Citing both Spanish law and the remoteness of the islands, ${ }^{271}$ he decided that no "other grounds" for attacking the deportation existed. Thus, the Governor General's act was a legitimate act of state, not subject to judicial review. ${ }^{272}$

To read Tiaco to sanction unlimited power to expel summarily without judicial review is to reach a result not justified by the prior cases dealing with the right of aliens to test their right to remain, ${ }^{273}$ and not required by Tiaco's facts. The view that there need be no hearing in expulsion cases has been discarded by subsequent decisions. ${ }^{274}$ Even in Tiaco the aliens obtained a full review of the question of whether the deportation was a legitimate exercise of governmental power. The only certain conclusion from the case is that it involved a peculiar factual situation, rested upon special legal bases, and thus can shed little if any light on the problem of congressional power to expel on the mainland. ${ }^{275}$

Bugajewitz and the Pitfalls of Terseness. In Bugajewitz v. Adams ${ }^{276}$ the Court considered section 3 of the 1907 act as altered by the 1910 amendments. ${ }^{277}$ The record showed that Bugajewitz was

an alien; that she entered the United States not later than January 4, 1905 , and that she was arrested on August 3,1910 ... [The order of arrest] recited that she was then a prostitute and inmate of a house of prostitution, and that she was a prostitute at the time of entry and entered the United States for the purpose of prostitution or for an immoral purpose .... [She denied] that she was a prostitute at the time of entry, or that she entered for any of the purposes alleged . . . ${ }^{278}$

Thus, the Government's theory was that Bugajewitz was erroneously admitted, while her defense was that she was properly admitted, and that what-

271. Ibid.

272. Id. at 558 .

273. E.g., Chin Yow v. United States, 208 U.S. 8 (1908); The Japanese Immigrant Case, 189 U.S. 86 (1903); Nishimura Ekiu v. United States, 142 U.S. 651 (1892).

274. See, e.g., Shaughnessy v. United States ex rel. Mezei, 345 U.S. 206 (1953) (dictum); Wong Yang Sung v. McGrath, 339 U.S. 33 (1950).

275. The so-called "Insular Cases," Balzac v. Porto Rico, 258 U.S. 298 (1922) ; Dorr v. United States, 195 U.S. 138 (1904); Hawaii v. Mankichi, 190 U.S. 197 (1903); Downes v. Bidwell, 182 U.S. 244 (1901), with which Tiaco belongs historically, were recently limited to their special historical setting in Reid v. Covert, 354 U.S. 1, 13 (1957).

Mr. Justice Black's views on limitation of constitutional rights in times of emergency are particularly apropos:

Neither the cases nor their reasoning should be given any further expansion. The concept that the Bill of Rights and other constitutional protections against arbitrary government are inoperative when they become inconvenient or when expediency dictates otherwise is a very dangerous doctrine and if allowed to flourish would destroy the benefit of a written Constitution and undermine the basis of our Government.

Id. at 14 .

276. 228 U.S. 585 (1913).

277. Act of Feb. 20, 1907, ch. 1134, § 3, 34 Stat. 899, as amended, Act of March 26, 1910, ch. 128, § 2, 36 Stat. 265.

278. 228 U.S. at 590. 
ever her present condition, it arose subsequent to entry. To this Mr. Justice Holmes replied that "we must take it, at least, that she is a prostitute now."270 The almost universal reading of this condemning statement is that there is no question regarding congressional power to expel for unsavory acts occurring subsequent to entry. An equally legitimate interpretation, however, is that since Bugajewitz was admittedly then a prostitute, she was, prima facie at least, deemed to have entered as a prostitute. This position is all the more plausible in view of Holmes' dissent in Keller, which dealt with the power of Congress to raise a conclusive presumption of erroneous admittance from postentry conduct. 280

Since Bugajewitz had not been apprehended until over five years after entry and had alleged proper admittance, it might have been expected that her counsel would argue that the presumption was invalid in her case. But his constitutional contentions were limited to the assertion of alleged denials of her procedural rights-that she was being deported for a crime and had been deprived of a judicial hearing. ${ }^{281}$ It is probably safe to surmise, therefore, that Bugajewitz could offer no conclusive proof that she had not entered as a prostitute. Thus, her position was analogous to that of the Chinese laborers in Fong Yue Ting, and the statute may be viewed as a valid regulation of immigration as applied to her. ${ }^{282}$

Thus, the brusque conclusion of the opinion is subject to an interpretation different from the one that has been generally accepted. Mr. Justice Holmes' words were:

The attempt to reopen the constitutional question must fail. It is thoroughly established that Congress has power to order the deportation of aliens whose presence in the country it deems hurtful. The determination by facts that might constitute a crime under local law is not a conviction of a crime, nor is deportation a punishment; it is simply a refusal by the government to harbor persons whom it does not want. The coincidence of the local penal law with the policy of Congress is an accident. Fong Yue Ting v. United States, 149 U.S. 698, 707, 728, 730. Wong Wing v. United States, 163 U.S. 228, 231. Zakonaite v. Wolf, 226 U.S. 272, 275. Tiaco v. Forbes .... The prohibition of ex post facto laws in Article 1, $\S 9$, has no application, Johannessen v. United States, 225 U.S. 227, 242, and with regard to the petitioner, it is not necessary to construe the statute as having any retrospective effect. ${ }^{283}$

The previous analysis of the cases cited has shown that none of them involved upholding an exercise of the power to expel against substantive due process objections. Admittedly, some of the language of Fong Yue Ting at the locations cited seems at first glance to point to such a result. But the

279. Ibid.

280. See text at note 193 supra. On the record in Keller, the woman involved did not become a prostitute until almost three years after her entry. 213 U.S. at 147.

281. 228 U.S. at 586-89.

282. Compare text at notes 102-04 supra.

283. 228 U.S. at 591. 
specific citations to Wong Wing and Zakonaite involved only procedural matters, and, as has been noted, Tiaco is not clear authority for the existence of unlimited sovereign power. It would seem that if Holmes had intended to decide substantive due process questions, he would have considered Keller relevant. Indeed, since the substantive issue was not raised by counsel, and since its consideration was not necessarily required by the statute, the assumption that it was disposed of is unjustified without some positive indication other than the cases cited. But the language of the opinion does not provide such an indication.

By refusing to "reopen the constitutional question" Mr. Justice Holmes implied that he felt he was confronted with a closed issue. But the issue of substantive limits, which Bugajezritz is now assumed to have settled, had been left open in Keller and was still open. Moreover, it cannot reasonably be contended that there is only one possible constitutional issue involved in the banishment of long-term, lawful permanent residents. "The constitutional question" to which Holmes referred must have been the procedural due process issue raised by counsel for Bugajewitz. That issue was settled by all four of the cases relied on. If this interpretation is correct, then the immediately subsequent statement, regarding the power of Congress to expel aliens "whose presence ... it deems hurtful," should not be read to countenance unlimited power. ${ }^{284}$ In the context in which the statement is made, it can be argued that Holmes intended to go no farther than the point decided in Zakonaitethat Congress' power to prescribe valid regulations of immigration is not limited by the coincidence of such regulations with state criminal law.

The concluding sentence offers further evidence that the facts on which a substantive due process issue could have been raised and decided were not before the Court. Holmes relied on the Johannessen ${ }^{285}$ case to dispose of the ex post facto problem. Johannessen dealt with the power to denaturalize one who had obtained citizenship by fraud concerning length of residence, and concluded that since Johannessen's constitutional status was never properly acquired, he could not object on the grounds of retroactivity to legislation which deprived him of that status. ${ }^{286}$ This citation would seem inapposite if the Court in Bugajezitz was dealing with a lawful permanent resident. On the other hand, reliance on Johannessen is consistent with the theory that Bugajewitz-to put the case most strongly in her favor-could not prove that she had not been erroneously admitted. If her status as a resident was considered to have been obtained erroneously, it becomes clear why she could not

284. Admittedly, it has been so understood. See Carlson v. Landon, 342 U.S. 524, 536 (1952) ; Ng Fung Ho v. White, 259 U.S. 276, 280 (1922). See also H.R. 9766, 76th Cong., 3d Sess. (1940), a bill to expel Harry Bridges, "whose presence in this country the Congress deems hurtful." The bill passed the House but was defeated in committee in the Senate. Its supporters relied on Tiaco. See S. REp. No. 2031, 76th Cong., 3d Sess., pt. 2, at 5-9 (1940).

285. Johannessen v. United States, 225 U.S. 227 (1912).

286. Id. at $242-43$. 
rely on the constitutional prohibition of ex post facto laws, and how Holmes was able to say that "with regard to the petitioner it is not necessary to construe the statute as having any retrospective effect." 287

This last statement cannot easily be reconciled with the theory that the case dealt with the status of a lawful permanent resident. Bugajewitz entered the country "not later than January 4, 1905."288 By January 5, 1908, therefore, she was immune from ejection under the 1907 statute. 289 She was arrested less than five months after the three-year limitation period was eliminated by the 1910 amendments. If the Court had considered her a properly admitted resident, the retrospective effect of the statute would seem impossible to deny. Only by hypothesizing that the Court assumed that Bugajewitz was excludable as a prostitute under the 1903 act ${ }^{290}$ at the time of her entry is the conclusion understandable.

It is, of course, possible that Holmes' views on the extent of congressional power over aliens had significantly changed since his Keller dissent, and that he was ready to accept the idea of banishment for postentry acts, whether or not connected with preentry conditions. ${ }^{291}$ Before this conclusion is reached, however, it should be noted that Holmes apparently regarded prostitutes as suffering from permanent personal defects. ${ }^{292}$ This theory undoubtedly colored his thinking about the validity of the conclusive presumption of erroneous admittance as applied in this case. Thus, he might well have accepted a presumption unlimited in time and based on the alien's present activities, and still not approved of present-day statutes which provide for banishment on the basis of activities neither related to preentry characteristics nor presently carried on. ${ }^{293}$

But it seems more likely that Holmes simply did not consider that the validity of the presumption was at issue in Bugajewitz. ${ }^{204}$ The internal evi-

287. 228 U.S. at 591.

288. Id. at 590 .

289. Act of Feb. 20, 1907, ch. 1134, 34 Stat. 900.

290. Act of March 3, 1903, ch. 1012, § 2, 32 Stat. 1214.

291. He may well have been willing to accept a longer limitation period. Cf. Luria v. United States, 231 U.S. 9, 27 (1913) (presumption in denaturalization cases).

292. See Gegiow v. Uhl, 239 U.S. 3, 10 (1915). This "once a prostitute, always a prostitute" approach is similar to the rationale behind the expulsion provisions concerning crimes involving moral turpitude. See S. REp. No. 352, 64th Cong., 1st Sess. 15 (1916), reporting on the Act of Feb. 5, 1917, ch. 29, 39 Stat. 874, which enacted the first "moral turpitude" expulsion clause. This rationale, while it may be open to criticism on policy grounds, is consistent with the conditional entry theory of expulsion.

293. As an example, the Immigration and Nationality Act of 1952, 66 Stat. 163, 8 U.S.C. $\$ \S 1101-503$ (1952), in addition to the well known provisions relating to Communists, 66 Stat. 205, 8 U.S.C. $\$ 1251$ (a) (b)'(c) (1952), authorizes deportation of aliens who have at any time been convicted of possessing a sawed-off shotgun, 66 Stat. 207, 8 U.S.C. \& 1251 (a) (14) (1952).

294. Possibly counsel for Bugajewitz was incompetent or negligent in failing to press the substantive due process issue. That this significantly affected the opinion seems improbable for Holmes disposed of the question of legislative intent with respect to the 
dence of the opinion strongly indicates that he assumed the presence of an erroneously admitted alien. In any event, the theory advanced here is certainly a tenable explanation of a terse opinion which, to say the least, demands interpretation.

\section{CoNCLUSION}

From the foregoing analysis it can be seen that the legislation approved in the pre-1917 cases dealt with illegally or erroneously admitted aliens. ${ }^{295}$ With the issue of substantive due process seldom squarely raised, it was perhaps inevitable that the Supreme Court should use language describing the scope of the power to expel in broad terms. But Holmes' definition of the scope of the power shows that congressional regulation of aliens might well be substantively limited in spite of the Court's earlier use of phrases such as "inherent sovereignty." 206

Congress' continued assertions of wider power since 1917 have been met, however, not with the imposition of substantive limits, but with the continued repetition of the inherent sovereignty formula. The post-1917 transition from ejection to banishment will be treated in the second Article.

removal of the three-year limitation in $\S 3$ of the act without the issue being raised by counsel. 228 U.S. at 590-91. If the facts were such that a serious question of the application of the conclusive presumption had been presented, therefore, he probably would have raised this far more basic argument, as he had previously indicated in Keller that three years was close to the line of constitutional validity.

295. Two post-Bugajezvitz cases, Lewis v. Frick, 233 U.S. 291 (1914); Lapina v. Williams, 232 U.S. 78 (1914), involved aliens expelled within three years of reentry into the United States. In each case, the alien was excludable at the time of reentry.

296. Keller v. United States, 213 U.S. 138, 149-51 (1909) (dissenting opinion); see text at notes $189-97$ supra. 


\section{THE YALE LAW JOURNAL}

VOLUME 68 JULY 1959 NUMBER 8

\author{
MItCHer J. Ezer \\ Burt W. GrifFin \\ JeRoLD H. IsRaeI \\ MichaEI J. NASSAU \\ Alan L. Wurtzet \\ Note and Comment \\ Editors
}

Matthew T. Adams

David Albenda

Alan Appetbaum

ROBERT L. BARD

ARTHUR J. BERK

Norman A. Bikales

Benjamin W. Boley

Richard A. Brady

Peter D. Calpwell

JAMES M. EdWARDS

Eltezer Ereit

David R. Evans

J. EDWARD Fowler

THOMAS N. FROHOCK

DATID GOLDBERG

\section{SydNey M. CONE, III}

Editor-in-Chief

Stuart B. Goldman

RICHARD S. HARRISON

NerL S. HeCHT

Reuben L. Hedlund

JACOB W. HeLleR

Benjamin T. Hopkins, II

JAMES M. JoHNSTONE

WiLliam A. Kass

N. Herschel Koblenz

EUGENE I. LAMBERT

J. D. LAMBERT

IRVING I. LESNICK

JoHN C. MCGuIRE

FREDERICK W. MCNABB, JR.

Stephen ManN

Donald G. Marshail

\author{
ROBERT J. ENGeLANAN \\ JoHN K. MCNulty \\ Article and Book \\ Review Editors \\ T. Cecil Wray, Jr. \\ Managing Editor
}

Bruce Montgontery

SAMUEL MYERS

J. Arexander Onderdonk

Alan D. PERELNER

Charters J. Prentiss

Herbert Schretber

BARRY SiDMAaN

Richard LaUder Sutton

Colin C. TAIT

JoHN W. VANDOREN

GILBERT PAUL Verbit

HERBERT S. WANDER

Donald P. WeTER

Patricta W. Weinberg

ROBERT L. WEINBERG

Marie MCMahoN

Business Secretary

\section{CONTRIBUTORS TO THIS ISSUE}

Helen Silving. Dr. Pol. Sci., Dr. Jur., University of Vienna; LL.B., Columbia University. Member of the New York Bar. Attorney, U.S. Department of Justice, 1948-1953; Research Associate, Harvard Law School, 1954-1956; Professor of Law, University of Puerto Rico, since 1956. Visiting Lecturer and Senior Fellow, Yale Law School, 1958-1959.

SiEgrried HesSe. A.B. 1946, University of Southern California; LL.B. 1950, University of California (Berkeley). Member of the Washington Bar. Managing Legal Editor, California Continuing Education of the Bar. 